\title{
Million-year-scale alternation of warm-humid and semi-arid periods as a mid-latitude climate mode in the Early Jurassic (late Sinemurian, Laurasian Seaway)
}

\author{
Thomas Munier $^{1,2}$, Jean-François Deconinck ${ }^{1}$, Pierre Pellenard ${ }^{1}$, Stephen P. Hesselbo ${ }^{3}$, James B. Riding $^{4}$, \\ Clemens V. Ullmann ${ }^{3}$, Cédric Bougeault ${ }^{1}$, Mathilde Mercuzot ${ }^{5}$, Anne-Lise Santoni ${ }^{1}$, Émilia Huret ${ }^{6}$, and \\ Philippe Landrein ${ }^{6}$ \\ ${ }^{1}$ Biogéosciences, UMR 6282, uB/CNRS, Université Bourgogne Franche-Comté, 6 Boulevard Gabriel, 21000 Dijon, France \\ ${ }^{2}$ ISTeP, UMR 7193, SU/CNRS, Sorbonne Université, 4 Place Jussieu, 75005 Paris, France \\ ${ }^{3}$ Camborne School of Mines and the Environment and Sustainability Institute, University of Exeter, Penryn Campus, \\ Penryn, Cornwall TR10 9FE, UK \\ ${ }^{4}$ British Geological Survey, Keyworth, Nottingham NG12 5GG, UK \\ ${ }^{5}$ Géosciences Rennes, UMR 6118, UR/CNRS, Université Rennes 1, Campus de Beaulieu, \\ CS 7420535042 Rennes CEDEX, France \\ ${ }^{6}$ Agence Nationale pour la gestion des déchets radioactifs, Centre de Meuse/Haute-Marne, RD 960, 55290 Bure, France
}

Correspondence: Thomas Munier (thomas.munier@sorbonne-universite.fr)

Received: 16 July 2020 - Discussion started: 10 September 2020

Revised: 19 May 2021 - Accepted: 28 May 2021 - Published: 21 July 2021

\begin{abstract}
Clay mineral and stable isotope $(\mathrm{C}, \mathrm{O})$ data are reported from the upper Sinemurian (Lower Jurassic) of the Cardigan Bay Basin (Llanbedr-Mochras Farm borehole, northwestern Wales) and the Paris Basin (Montcornet borehole, northern France) to highlight the prevailing environmental and climatic conditions. In both basins, located at similar palaeolatitudes of $30-35^{\circ} \mathrm{N}$, the clay mineral assemblages comprise chlorite, illite, illite-smectite mixed layers (R1 I-S), smectite, and kaolinite in various proportions. Because the influence of burial diagenesis and authigenesis is negligible in both boreholes, the clay minerals are interpreted to be derived from the erosion of the Caledonian and Variscan massifs, including their basement and pedogenic cover. In the Cardigan Bay Basin, the variations in the proportions of smectite and kaolinite are inversely related to each other through the entire upper Sinemurian. As in the succeeding Pliensbachian, the upper Sinemurian stratigraphic distribution reveals an alternation of kaoliniterich intervals reflecting strong hydrolysing conditions and smectite-rich intervals indicating a semi-arid climate. Kaolinite is particularly abundant in the upper part of the obtusum zone and in the oxynotum zone, suggesting more intense hy-
\end{abstract}

drolysing conditions likely coeval with warm conditions responsible for an acceleration of the hydrological cycle. In the north of the Paris Basin, the succession is less continuous compared to the Cardigan Bay Basin site, as the oxynotum zone and the upper raricostatum zone are either absent or highly condensed. The clay assemblages are dominantly composed of illite and kaolinite without significant stratigraphic trends, but a smectite-rich interval identified in the obtusum zone is interpreted as a consequence of the emersion of the London-Brabant Massif following a lowering of sea level. Following a slight negative carbon isotope excursion at the obtusum-oxynotum zone transition, a long-term decrease in $\delta^{13} \mathrm{C}_{\text {org }}$ from the late oxynotum-early raricostatum zones is recorded in the two sites and may precede or partly include the negative carbon isotope excursion of the Sinemurian-Pliensbachian Boundary Event, which is recognised in most basins worldwide and interpreted to signify a late pulse of the Central Atlantic Magmatic Province volcanism. 


\section{Introduction}

The Early Jurassic is characterised by major palaeogeographical changes induced by the breakup of Pangaea. This geodynamic evolution is accompanied by intense volcanic activity corresponding to the Central Atlantic Magmatic Province (CAMP) beginning at the Triassic-Jurassic boundary 201.5 million years ago (Marzoli et al., 1999; McHone, 2000; Davies et al., 2017), and it is likely responsible for the end-Triassic mass extinction (see e.g. Korte et al., 2019, and references therein). The breakup of Pangaea led to the opening of the Hispanic and Viking corridors, connecting the Tethys Ocean to Panthalassa and the Arctic Ocean, respectively (Bjerrum et al., 2001; van de Schootbrugge et al., 2005; Damborenea et al., 2013; Porter et al., 2013). The disintegration of Pangaea resulted in the formation of many sedimentary basins, and palaeogeographical changes led to exchanges of water masses that triggered climate fluctuations with colder intervals (Dera et al., 2011) over a prolonged greenhouse period (Chandler et al., 1992; Dera et al., 2009a, 2015; Korte et al., 2015).

Reconstructions of seawater temperatures through the Early Jurassic are mostly deduced from $\delta^{18} \mathrm{O}$ measurements of belemnite rostra and some other mollusc shells, notably oysters. For the late Sinemurian, oxygen isotope data $\left(\delta^{18} \mathrm{O}_{\text {carb }}\right.$ and $\left.\delta^{18} \mathrm{O}_{\text {bel }}\right)$ show increasing values over time (Dera et al., 2011), indicating cooler ocean temperatures as recorded, for example, in the Cleveland Basin (Hesselbo et al., 2000; Korte and Hesselbo, 2011) and the Asturian Basin (Gómez et al., 2016). However, warmer conditions also seem to have prevailed episodically, for example, during the oxynotum zone (Riding et al., 2013; Hesselbo et al., 2020).

The carbon cycle also shows perturbations, with negative carbon isotope excursions recorded either by $\delta^{13} \mathrm{C}_{\mathrm{carb}}$ or $\delta^{13} \mathrm{C}_{\text {org }}$. The best documented of these excursions is the Sinemurian-Pliensbachian Boundary Event (SPBE or S-P Event), which is recognised in many areas, including, among others the Cleveland Basin (Hesselbo et al., 2000; Jenkyns et al., 2002; Korte and Hesselbo, 2011), the Wessex Basin in Dorset (Jenkyns and Weedon, 2013; Price et al., 2016; Schöllhorn et al., 2020a), the Cardigan Bay Basin in western Wales (van de Schootbrugge et al., 2005; Hesselbo et al., 2013; Storm et al., 2020), the Lusitanian Basin (Duarte et al., 2014; Plancq et al., 2016), the Lombardian Basin and Trento platform (Franceschi et al., 2019), the Paris Basin (Peti et al., 2017; Bougeault et al., 2017), and the Central High Atlas Basin of Morocco (Danisch et al., 2019; Mercuzot et al., 2020). This negative excursion is recorded in carbonate rocks $\left(\delta^{13} \mathrm{C}_{\mathrm{carb}}\right)$, belemnite rostra $\left(\delta^{13} \mathrm{C}_{\mathrm{bel}}\right)$, and organic matter $\left(\delta^{13} \mathrm{C}_{\mathrm{org}}\right)$, including fossil wood.

Another $\delta^{13} \mathrm{C}_{\text {org }}$ negative excursion was also first recognised in the upper part of the obtusum zone and through the oxynotum zone in eastern England (Riding et al., 2013; Hesselbo et al., 2020), and it is recorded in Dorset (southern England; Jenkyns and Weedon, 2013), in the Mochras borehole (Storm et al., 2020), and in the southern Alps in Italy from shallow-water carbonate platforms to deep offshore environments (Masetti et al., 2017). This excursion coincides with increasing proportions of two thermophilic palynomorph taxa, Classopollis classoides, a terrestrially derived pollen grain, and Liasidium variabile, a marine dinoflagellate cyst, suggesting that the obtusum-oxynotum zone transition was a warm and/or dry interval. Liasidium variabile, a reliable index for the upper Sinemurian in northwestern Europe (Brittain et al., 2010; van de Schootbrugge et al., 2019), may have invaded the Tethys Ocean from Panthalassa after the opening of the Hispanic Corridor (van de Schootbrugge et al., 2005). This species is particularly abundant in the oxynotum zone, and the name Liasidium Event is used to describe the complex of environmental changes at this time (Hesselbo et al., 2020).

Humidity is also a key parameter of climate, but it is still poorly documented over this period. Palynological data are focused on Classopollis pollen, which is very common in the obtusum and oxynotum zones, whether in the Cardigan Bay (Wall, 1965; van de Schootbrugge et al., 2005), the Cleveland (Riding et al., 2013), or the Lusitanian (Poças Ribiero et al., 2013) basins.

The composition of clay mineral assemblages can be a reliable climate indicator (Chamley, 1989; Ruffell et al., 2002; Raucsik and Varga, 2008; Dera et al., 2009b) provided their dominant detrital origin can be demonstrated. Clay mineral assemblages may reflect the intensity of hydrolysis during pedogenic processes and runoff conditions on land masses, and they thus specify humidity variations from the signal recorded in marine sedimentary series. In the upper Sinemurian, variations of clay mineral assemblages have been studied on several outcrops and boreholes from the British Isles (Jeans, 2006; Kemp et al., 2005; Hesselbo et al., 2020) and in the Montcornet borehole north of the Paris Basin (Debrabant et al., 1992), but at low resolution, only for a short interval, or in successions affected by strong clay mineral diagenesis. Here we attempt, through a study of detrital clay mineral assemblages and fluctuations in stable isotopes ( $\mathrm{C}$ and $\mathrm{O})$ of upper Sinemurian strata from the Llanbedr (Mochras Farm) and the Montcornet boreholes, to estimate the intensity of chemical weathering and hydrolysis, as well as the magnitude of carbon cycle changes.

\section{Geological background}

During the Early Jurassic, the Paris and Cardigan Bay basins were located to the northwest of the Tethyan domain. This area corresponded to an archipelago of large islands inherited from Caledonian and Variscan massifs (Thierry et al., 2000). These continental masses, such as the London-Brabant Massif, the Massif Central, the Armorican Massif, and the Welsh High, were surrounded by an epicontinental sea (Fig. 1). An excellent sedimentary record of the Early Jurassic is pre- 


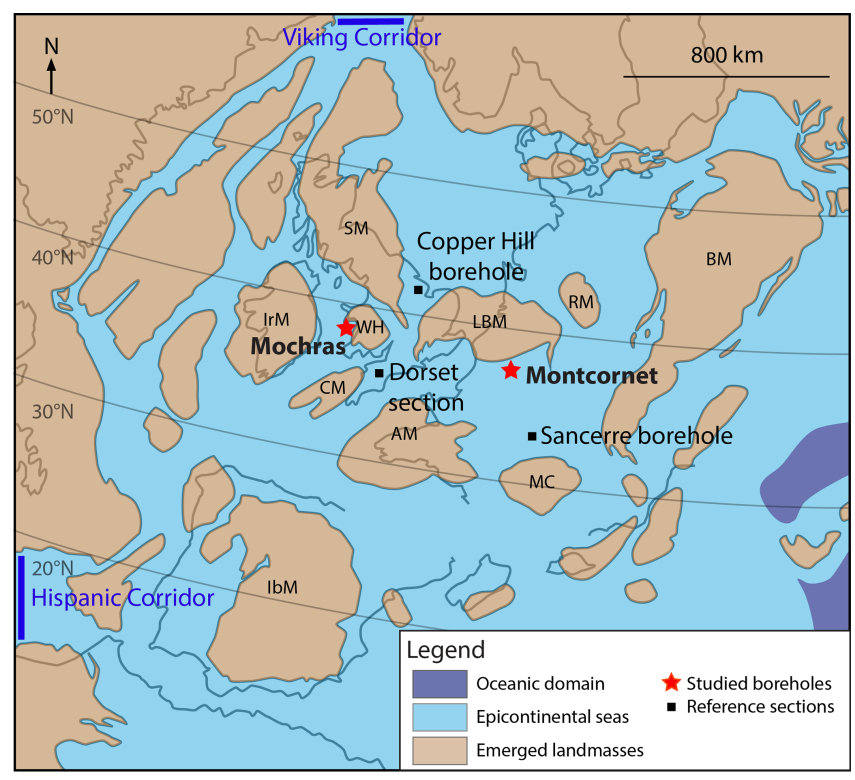

Figure 1. Upper Sinemurian palaeogeographical map of the northwestern Tethyan domain and position of the studied boreholes (modified from Bougeault et al., 2017). Abbreviations: SM - Scottish Massif; IrM - Irish Massif; CM - Cornubian Massif; WH Welsh High; LBM - London-Brabant Massif; RM - Rhenish Massif; BM - Bohemian Massif; MC - Massif Central; AM - Armorican Massif; IbM - Iberian Massif.

served at both study locations due to the extensional context linked to the breakup of Pangaea and related thermal and tectonic subsidence (Woodland, 1971; Corcoran and Clayton, 1999; Guillocheau et al., 2000; Beccaletto et al., 2011; Hesselbo et al., 2013).

\subsection{The Llanbedr (Mochras Farm) borehole, Cardigan Bay Basin, Wales}

The Cardigan Bay Basin, located in western Wales between the Welsh High and the Irish Massif (Fig. 1), corresponds to a half-graben basin (Dobson and Whittington, 1987; Tappin et al., 1994; Holford et al., 2005) bounded at the end of the Paleozoic by a major active fault (the Mochras Fault) with an offset of almost $4500 \mathrm{~m}$ (Wood and Woodland, 1968; Woodland, 1971; Hesselbo et al., 2013). This basin was located at a latitude between 35 and $40^{\circ} \mathrm{N}$ (Fig. 1; Thierry et al., 2000; Osete et al., 2011). Lower Jurassic strata reach $\sim 1300 \mathrm{~m}$ in thickness (Woodland, 1971; Ruhl et al., 2016). Cretaceous strata are rare or absent because of erosion following thermal uplift and inversion processes (Woodland, 1971; Tucker and Arter, 1987; Tappin et al., 1994), while the thickness of Cenozoic sedimentary rocks reaches $600 \mathrm{~m}$.

The Llanbedr (Mochras Farm) borehole, commonly abbreviated to Mochras, was drilled and continuously cored ( $\sim 85 \mathrm{~mm}$ diameter for the Sinemurian) between 1967 and 1969 on the coast in northwestern Wales, UK (Fig. 2) (Wood-

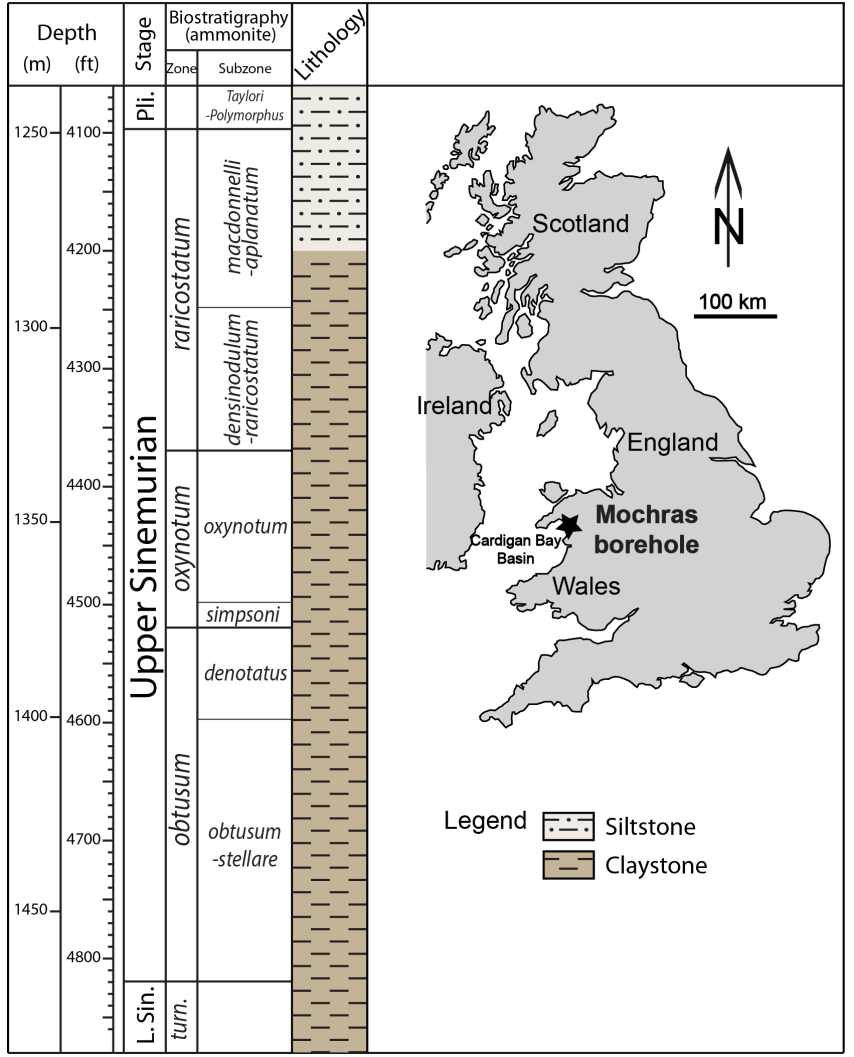

Figure 2. Location map of the Mochras borehole, simplified lithology, and biostratigraphy of the upper Sinemurian (from Copestake and Johnson, 2014). Abbreviations: L. Sin. - lower Sinemurian, Pli. - Pliensbachian, turn. - turneri.

land, 1971; Hesselbo et al., 2013). The Lower Jurassic deposits consist of a continuous succession of marls and claystones, fully cored, making this borehole a reference for environmental and climatic reconstructions for the Early Jurassic (Hesselbo et al., 2013).

The $220 \mathrm{~m}$ thick upper Sinemurian strata consist of relatively homogeneous marl and clayey mudstone, with more silt in the upper part of the raricostatum zone. Veins of calcite and pyrite commonly occur and siderite nodules are present, particularly in the oxynotum zone. It has previously been suggested that this calcite-veined level may have been the consequence of faulting, leading to minor stratigraphical offset not detectable by current biostratigraphy (Woodland, 1971; Storm et al., 2020), but there is no positive evidence for strata missing due to tectonism.

Following the zonation proposed by Page (2003), a precise biostratigraphical scheme is established based on the frequent occurrence of ammonites (Hesselbo et al., 2013; Copestake and Johnson, 2014). The obtusum zone extends from 1468 to $1376 \mathrm{~m}$ and is overlain by the oxynotum zone to $1332 \mathrm{~m}$ and the raricostatum zone from 1332 to $1249 \mathrm{~m}$ (Woodland, 1971; Page in Copestake and Johnson, 2014). 


\subsection{Montcornet borehole, Paris Basin, France}

During the Early Jurassic, the Paris Basin was bordered by continental masses, which are remnants of the Paleozoic orogenic belts (Fig. 1). The main land masses include the London-Brabant Massif (LBM), the Armorican Massif, the Massif Central, and the Bohemian Massif (Guillocheau et al., 2000; Thierry et al., 2000).

The Montcornet borehole (borehole Andra A901) was drilled (continuously cored with an $85 \mathrm{~mm}$ diameter) in 1989 near the village of Montcornet to the north of the Paris Basin (Fig. 3) by Andra, the French national radioactive waste management agency. The strata penetrated were deposited in an epicontinental sea located immediately south of the LBM at a palaeolatitude of approximately $35^{\circ} \mathrm{N}$, which is quite similar to the latitude of the Cardigan Bay Basin (Fig. 1). The stratigraphical succession extends from the Devonian metamorphic basement (shales) to the Turonian chalk, with a major gap occurring for the Lower Cretaceous, corresponding to the continental evolution of the Paris Basin (i.e. Wealden facies), from the Purbeckian deposits to the upper Albian transgressive claystones and marls (Debrabant et al., 1992). Above the siliciclastic continental Triassic deposits at a depth of $\sim$ $1075 \mathrm{~m}$, Jurassic strata nearly $870 \mathrm{~m}$ thick correspond mainly to open-marine limestones and marls (Yang et al., 1996).

The upper Sinemurian succession ( $\sim 50 \mathrm{~m}$, Fig. 4$)$, fully cored, consists of alternations of claystone, marl, and bioclastic limestone beds characterised by the presence of bivalves (Gryphaea), likely deposited in lower to upper offshore environments according to Yang et al. (1996).

Due to the irregular distribution of ammonites through the borehole, the biostratigraphic framework of the Montcornet borehole is less precise than at Mochras. Some new determinations (Jean-Louis Dommergues, personal communication, 2015) on ammonites found during the sampling complete the previous biostratigraphical scheme of Yang et al. (1996) and are illustrated in Fig. 4. Ammonites from the semicostatum zone (lower Sinemurian) are identified up to $976 \mathrm{~m}$, while the first ammonite from the obtusum zone occurs at $948.88 \mathrm{~m}$ with Promicroceras gr. planicosta (Yang et al., 1996, Fig. 4). The turneri zone is not identified but may be present between 976 and $948.88 \mathrm{~m}$. However, the occurrence of the dinoflagellate Liasidium variabile in this interval strongly suggests a late Sinemurian age, implying the absence of the turneri zone (see Fauconnier, 1995; Bucefalo Palliani and Riding, 2000) and the occurrence of the obtusum zone at $976 \mathrm{~m}$. The last ammonite of the obtusum zone is identified at $939.80 \mathrm{~m}$, while the first ammonite of the raricostatum zone is identified at $937.82 \mathrm{~m}$ (Yang et al., 1996) or slightly lower $(938.96 \mathrm{~m})$ according to new determinations of Crucilobiceras $\mathrm{sp}$. that would indicate the densinodulum subzone of the raricostatum zone (Fig. 4). No ammonites from the upper part of the obtusum zone or from the oxynotum zone have been found. This interval is, as is the case in the Wessex Basin in Dorset (Lang, 1945; Hallam, 1999; Hesselbo, 2008)

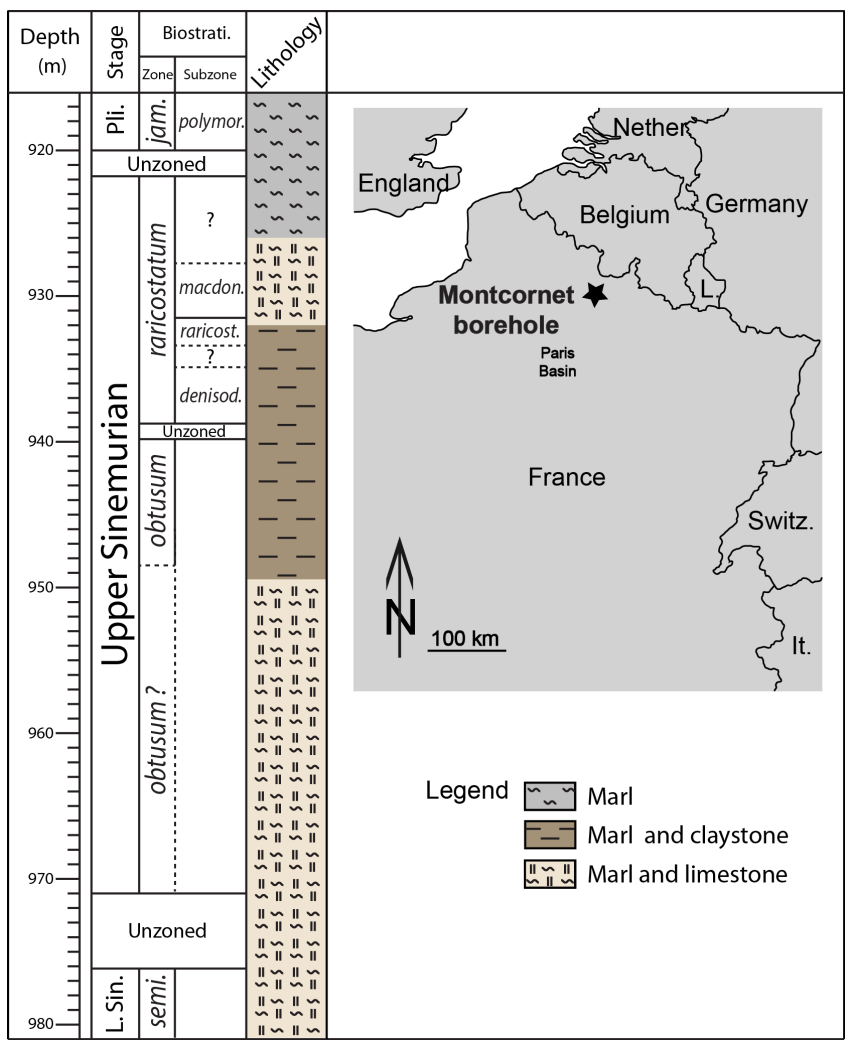

Figure 3. Location map of the Montcornet borehole, showing the simplified lithology and biostratigraphy of the upper Sinemurian (from Fauconnier, 1995; Yang et al., 1996). Abbreviations: densinod. - densinodulum, jam. - jamesoni, L. Sin - lower Sinemurian, macdonn. - macdonnelli, Pli. - Pliensbachian, polymor. polymorphus, raricost. - raricostatum, semi. - semicostatum.

and the Lower Saxony Basin of Germany (van de Schootbrugge et al., 2019), either absent or highly condensed in a $1 \mathrm{~m}$ thick interval without any identified ammonites between 939.80 and $938.96 \mathrm{~m}$. The last ammonites of the raricostatum zone are identified up to $921.75 \mathrm{~m}$, in agreement with the occurrence of Liasidium variabile up to $922 \mathrm{~m}$ (Fauconnier, 1995), while the first ammonites of the jamesoni zone appear from $920.6 \mathrm{~m}$, suggesting that the Sinemurian-Pliensbachian boundary is located at $\sim 921 \mathrm{~m}$ (Fig. 4). However, there are also some gaps at the Sinemurian-Pliensbachian transition since the upper part of the raricostatum zone is possibly missing (i.e. aplanatum subzone) and since the base of the jamesoni zone is also missing (i.e. taylori subzone). To conclude, the obtusum and raricostatum zones are wellidentified, while the oxynotum zone is either absent or highly condensed (Fig. 4). 

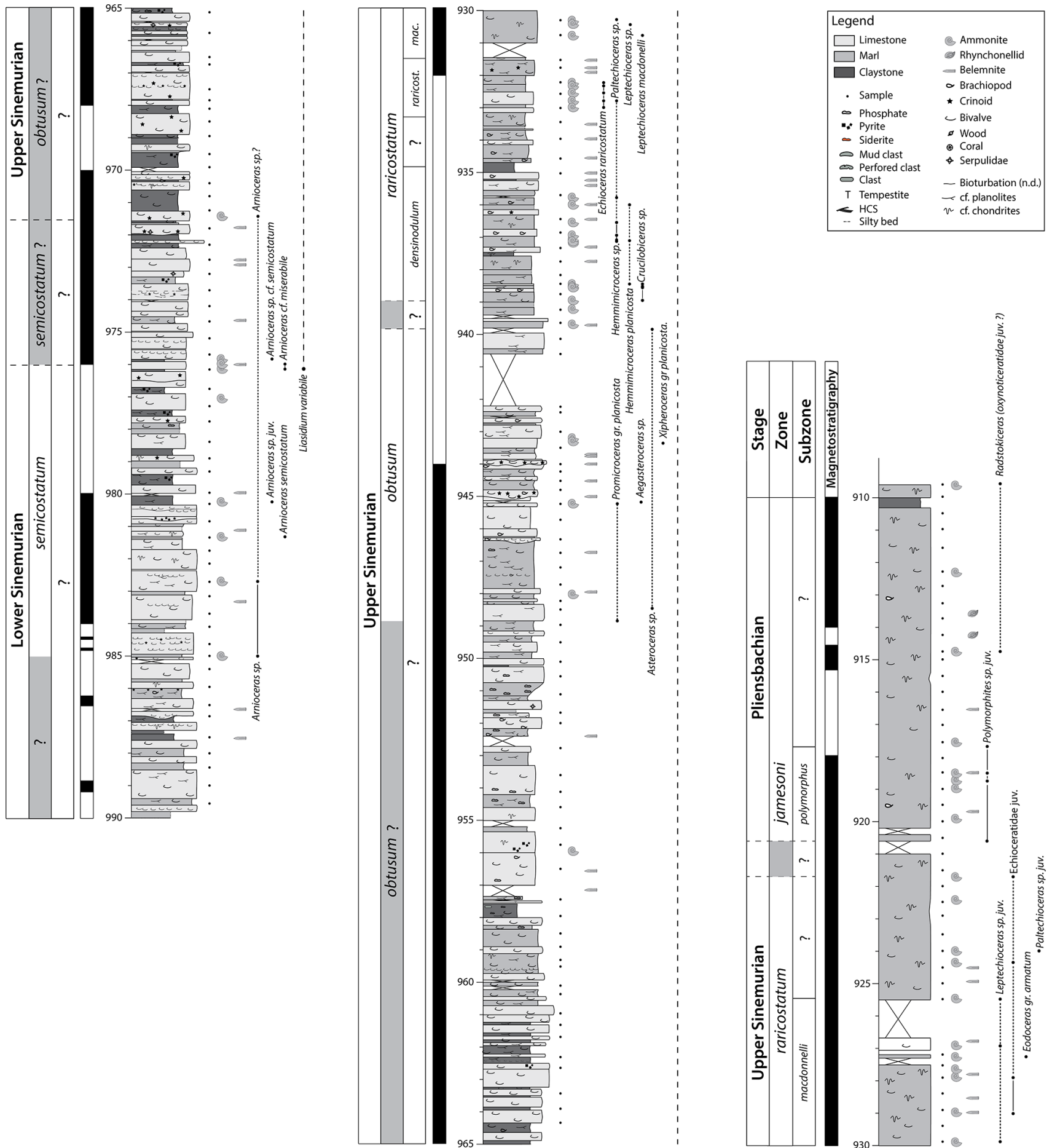

Figure 4. Detailed lithology, sampling, biostratigraphy, and magnetostratigraphy of the upper Sinemurian of the Montcornet borehole. Biostratigraphy modified from Yang et al. (1996) and Fauconnier (1995). Magnetostratigraphy from Yang et al. (1996) and Moreau et al. (2002). Gr. - group, juv. - juvenile, mac. - macdonnelli, semico. - semicostatum. 


\section{Material and methods}

\subsection{Clay mineral analyses}

A total of 223 samples were analysed using X-ray diffraction (XRD). After moderate grinding in a mortar, powdered samples were decarbonated with a $0.2 \mathrm{~N} \mathrm{HCl}$ solution. The $<2 \mu \mathrm{m}$ fraction (clay-sized particles) was extracted with a syringe after decantation of the suspension for $95 \mathrm{~min}$ following Stokes' law; this fraction was then centrifuged. Clay residue was then smeared on oriented glass slides and run in a Bruker D4 Endeavor diffractometer with $\mathrm{CuK}_{\alpha}$ radiation, a LynxEye detector, and a $\mathrm{Ni}$ filter with a voltage of $40 \mathrm{kV}$ and an intensity of $25 \mathrm{~mA}$ (biogeosciences laboratory, University of Burgundy, France). Goniometer scanning ranged from 2.5 to $28^{\circ}$ for each analysis. Three runs were performed for each sample to discriminate the clay phases: (1) air-drying; (2) ethylene-glycol solvation; and (3) heating at $490^{\circ} \mathrm{C}$ for $2 \mathrm{~h}$, as recommended by Moore and Reynolds (1997). Clay minerals were identified using their main diffraction $\left(d_{001}\right)$ peaks and by comparing the three diffractograms obtained. The following main clay minerals were identified: an R0-type illite-smectite mixed layer ( $17 \AA$ based on a glycolated run) referred to as smectite in the following sections; an R1-type illite-smectite mixed layer (around $11.5 \AA$ in air-drying conditions and $13 \AA$ after ethylene-glycol solvation); chlorite (14.2, 7.1, 4.7, and $3.54 \AA$ peaks); illite (10, 5, and $3.33 \AA$ peaks); and kaolinite (7.18 and $3.58 \AA$ peaks). Each clay mineral was quantified using the MacDiff software (version 4.2.5) (Petschick, 2000) on glycolated sample diffractograms. The area of main peaks $\left(d_{001}\right)$ is measured to estimate the proportion of each clay species by semi-quantification. As the main $\left(d_{001}\right)$ peak of kaolinite and the $\left(d_{002}\right)$ peak of chlorite overlap, a deconvolution procedure was applied to the $\left(d_{004}\right)$ peak area of chlorite $(3.54 \AA)$ and the $\left(d_{002}\right)$ peak area of kaolinite $(3.57 \AA)$ to accurately quantify both mineral portions using the 7.1 peak $\left(d_{001 \text { kaolinite }}+d_{002 \text { chlorite }}\right)$. Chlorite percentage was calculated using the mean between $\left(d_{001}\right)$ and $\left(d_{002}\right)$ chlorite peak areas considering that the chemical nature of chlorite impacts the $\left(d_{001}\right) /\left(d_{002}\right)$ ratio (Moore and Reynolds, 1997). The error margin of this method is approximatively $\pm 5 \%$ for the relative proportions of clay minerals in the clay fraction. The relative proportions of clay minerals are estimated using the ratios between the areas of the peaks, the most relevant of these being the $\mathrm{K} / \mathrm{I}$ and $\mathrm{Sm} / \mathrm{K}$ ratios.

\subsection{Geochemical preparation and analyses}

A total of 70 samples from the Mochras borehole and 38 samples from the Montcornet borehole were selected for $\delta^{13} \mathrm{C}_{\text {org }}$ analyses. Previously crushed $1 \mathrm{~g}$ samples underwent an acid digestion by $10 \mathrm{~mL}$ of $6 \mathrm{~N} \mathrm{HCl}$ solution for $48 \mathrm{~h}$, which represent a concentration and a duration justified by the common occurrence of dolomite. After cleaning with pure water, decarbonated powders were dried in an oven $\left(50^{\circ} \mathrm{C}\right.$ for 24 to $48 \mathrm{~h}$ ), then crushed again to obtain a fine powder. Each sample, of a specific mass ( 9 to $75 \mathrm{mg}$, depending on the former sample $\mathrm{CaCO}_{3}$ content), was weighed in a tin capsule with a Sartorius M2P ultrabalance. Samples were analysed with the Elementar MICRO cube elemental analyser coupled to an Elementar Isoprime 100 isotope ratio mass spectrometer. Isotope ratios obtained were compared to international standards USGS40 L-glutamic acid $\left({ }^{13} \mathrm{C}=-26.39 \pm 0.04 \%\right.$ VPDB $)$ and IAEA-600 caffeine $\left(\delta^{13} \mathrm{C}=-27.77 \pm 0.04 \%\right.$ VPDB $)$. For each sample, replicates showed reproducibility better than $\pm 0.15 \%$. The total organic carbon (TOC) content, expressed in wt \%, was determined by the elemental analyser at the same time.

Bulk rock carbon and oxygen isotope ratio analyses coupled with $\mathrm{CaCO}_{3}$ concentration measurements were carried out using a Sercon 20-22 triple detector gas-source isotope ratio mass spectrometer at the University of Exeter Penryn Campus following methods described in detail in Ullmann et al. (2020). Bulk rock powder extracted from rock fragments with a handheld drill was weighed at $1 \mu \mathrm{g}$ precision and transferred into borosilicate vials targeting an amount of $500 \mu \mathrm{g}$ of $\mathrm{CaCO}_{3}$ for analysis. Samples were flushed with $\mathrm{He}$ to remove atmospheric gases and then reacted with nominally anhydrous phosphoric acid ("103\%") at $70^{\circ} \mathrm{C}$. In a single batch 80 samples were analysed together with two in-house standards (22 aliquots of CAR Carrara marble, $\delta^{13} \mathrm{C}=+2.10 \%$ VPDB; $\delta^{18} \mathrm{O}=-2.03 \%$ 。 VPDB; 8 aliquots of NCA - Namibia carbonatite, $\delta^{13} \mathrm{C}=$ $-5.63 \%$ VPDB; $\delta^{18} \mathrm{O}=-21.90 \%$ VPDB). Instrumental drift and biases were corrected using a two-point calibration constrained by these two in-house standards. Accuracy was ensured via previous calibration of the in-house standards against international certified standards. $\mathrm{CaCO}_{3}$ content was computed from matching signal intensity of unknowns with CAR, which is assumed to be $100 \%$ pure $\mathrm{CaCO}_{3}$ (44 wt \% $\mathrm{CO}_{2}$ ). Reproducibility of the isotope ratio measurements for Mochras bulk rock samples based on analyses of CAR ( $2 \sigma$, $n=300$ ) is $0.07 \%$ for $\delta^{13} \mathrm{C}$ and $0.16 \%$ for $\delta^{18} \mathrm{O}$. Reproducibility of $\mathrm{CaCO}_{3}$ determinations is based on multiple analysis of NCA as an unknown, which gave $97.2 \pm 1.3 \%$ ( $2 \mathrm{SD}, n=132)$.

$\mathrm{CaCO}_{3}$ content was measured using a Bernard calcimeter (volumetric calcimetry) on samples, then completed by a weight-loss method (weight difference between the sample before and after decarbonation was performed prior to isotopic analyses of organic matter) for each sample. Each curve obtained for the geochemical data has been refined as a smoothed curve, and its $95 \%$ confidence intervals were acquired from a kernel-type regression using different levels of smoothing for each borehole. 


\section{Results}

\section{1 $\mathrm{CaCO}_{3}$ and total organic carbon (TOC) contents}

Calcite content from the upper Sinemurian of the Mochras borehole shows substantial fluctuations between $3 \%$ and $62 \%$ (Fig. 5). The lower Sinemurian-upper Sinemurian boundary is relatively rich in carbonate (up to $40 \%$ ), but the lowermost and the uppermost parts of the obtusum zone are depleted in $\mathrm{CaCO}_{3}(<10 \%)$, while in the middle part of this ammonite zone the $\mathrm{CaCO}_{3}$ content ranges from $20 \%$ to $4 \%$. The low $\mathrm{CaCO}_{3}$ content recorded at the top of the obtusum zone persists in the lower half of the oxynotum zone. Then, in the upper half of this zone and in the raricostatum zone, $\mathrm{CaCO}_{3}$ increases up to $60 \%$ (Fig. 5). In the Montcornet borehole $\mathrm{CaCO}_{3}$ content also fluctuates between $3 \%$ and $62 \%$ with similar trends, notably (1) a depletion in the uppermost part of the obtusum zone, although it is less well-expressed than in the Mochras borehole, likely because of the condensation of the series during this interval; and (2) a significant increase in the raricostatum zone (Fig. 6).

Total organic carbon (TOC) measurements are also similar between the two boreholes, with proportions around $1 \%$ (Figs. 7, 8). The lower Sinemurian-upper Sinemurian boundary is marked by a slightly higher TOC content (1.5\%), while the top of the obtusum zone shows a decrease in the proportion of organic carbon $(0.5 \%)$. In the Mochras borehole, the macdonnelli-aplanatum subzones of the raricostatum zone are enriched in TOC with values generally higher than $1.5 \%$ and reaching $3 \%$.

\subsection{Clay mineralogy}

\subsubsection{Mochras borehole}

Upper Sinemurian clay mineral assemblages are dominantly composed of chlorite ( $5 \%$ to $32 \%$ ), illite ( $15 \%$ to $42 \%$ ), R0type illite-smectite mixed layers, hereafter called smectite (10\% to $60 \%$ ), and kaolinite (4\% to $32 \%$ ). Minor proportions of R1-type illite-smectite mixed layers are commonly associated with these minerals. Significant fluctuations in the relative proportions of the different clay species are recorded through the core. The salient feature is the inverse relationship between smectite and kaolinite, which is particularly well-expressed by the $\mathrm{Sm} / \mathrm{K}$ ratio (Fig. 5). The opposition of these two minerals determines an alternation of kaoliniterich packages of sediments (lower part of obtusum, top of obtusum-base oxynotum, and median part of raricostatum) and smectite-rich packages of sediments (middle part of the obtusum zone, upper part of the oxynotum-base raricostatum zones, and upper part of the raricostatum zone).

The proportions of chlorite are relatively high and fluctuate in parallel with those of kaolinite. From the base to the top of the upper Sinemurian, the proportion of illite increases more or less regularly from $\sim 20 \%$ to $40 \%$.

\subsubsection{Montcornet borehole}

The clay mineral assemblages of the upper Sinemurian of the Montcornet borehole are composed of the same minerals as the Mochras borehole, but they show much less variation (Fig. 6). Illite is the most abundant clay mineral with proportions from $25 \%$ to $46 \%$, without any clear trend through the core. Kaolinite is also abundant, with proportions ranging from $6 \%$ to $32 \%$ and most samples having values close to $22 \%$. Chlorite shows lower percentages between $9 \%$ and $24 \%$ (average of $\sim 19 \%$ ). According to Debrabant et al. (1992), this mineral is associated with small proportions of chlorite-smectite mixed layers, which are undifferentiated in Fig. 6. R1-type illite-smectite mixed layers are relatively abundant between $5 \%$ and $26 \%$, notably in the middle part of the obtusum zone. Smectites are absent over a large part of the $56 \mathrm{~m}$ of upper Sinemurian, but these clay minerals occur in significant proportions (up to $33 \%$ ) in an $8 \mathrm{~m}$ thick interval between 965 and $973 \mathrm{~m}$ within the obtusum zone (Fig. 6).

\subsection{Carbon and oxygen isotope fluctuations}

\subsubsection{Mochras borehole}

Organic carbon isotope $\left(\delta^{13} \mathrm{C}_{\mathrm{org}}\right)$ values show significant variations (about $3.9 \%$ ) between $-24.47 \%$ and $-28.34 \%$ o over the upper Sinemurian succession (Fig. 7). $\delta^{13} \mathrm{C}_{\text {org }}$ values show the weakest variations in the obtusum and oxynotum zones (i.e. $\sim 1.5 \%$ ), while in the raricostatum zone, an irregular decrease in the values down to $-28 \%$ is recorded.

The $\delta^{13} \mathrm{C}_{\text {carb }}$ values show significant variations of more than $5 \%$, ranging between $+3.04 \%$ and $-2.21 \%$ VPDB (Fig. 7). A prominent negative shift $(\sim 3 \%$ ) is recorded at the transition between the obtusum and the oxynotum zones, followed by an increasing trend up to the topmost part of the Sinemurian. A slight negative shift $(1 \%$ ) is recorded at the transition between the densinodulum-raricostatum and macdonnelli-aplanatum subzones (Fig. 7).

The $\delta^{18} \mathrm{O}_{\text {carb }}$ values range from $-6.54 \%$ to $-2.61 \%$ o (Fig. 7). Very large fluctuations coupled to a scattered signal are recorded in the obtusum and oxynotum zones, while more constant values around $-4 \%$ are observed in the raricostatum zone. The major part of the oxynotum zone, however, corresponds to an interval characterised by lower values.

\subsubsection{Montcornet borehole}

The carbon isotope data $\left(\delta^{13} \mathrm{C}_{\mathrm{org}}\right)$ from the Montcornet borehole show values between $-26.49 \%$ and $-24.66 \%$ (Fig. 8). The trends and values are similar to those of the Mochras borehole, although fluctuations are less wellexpressed, likely due to the condensation of the series and the probable occurrence of hiatuses (i.e. oxynotum and late raricostatum zones). The values increase slightly from the base of the core to the transition between the obtusum and 


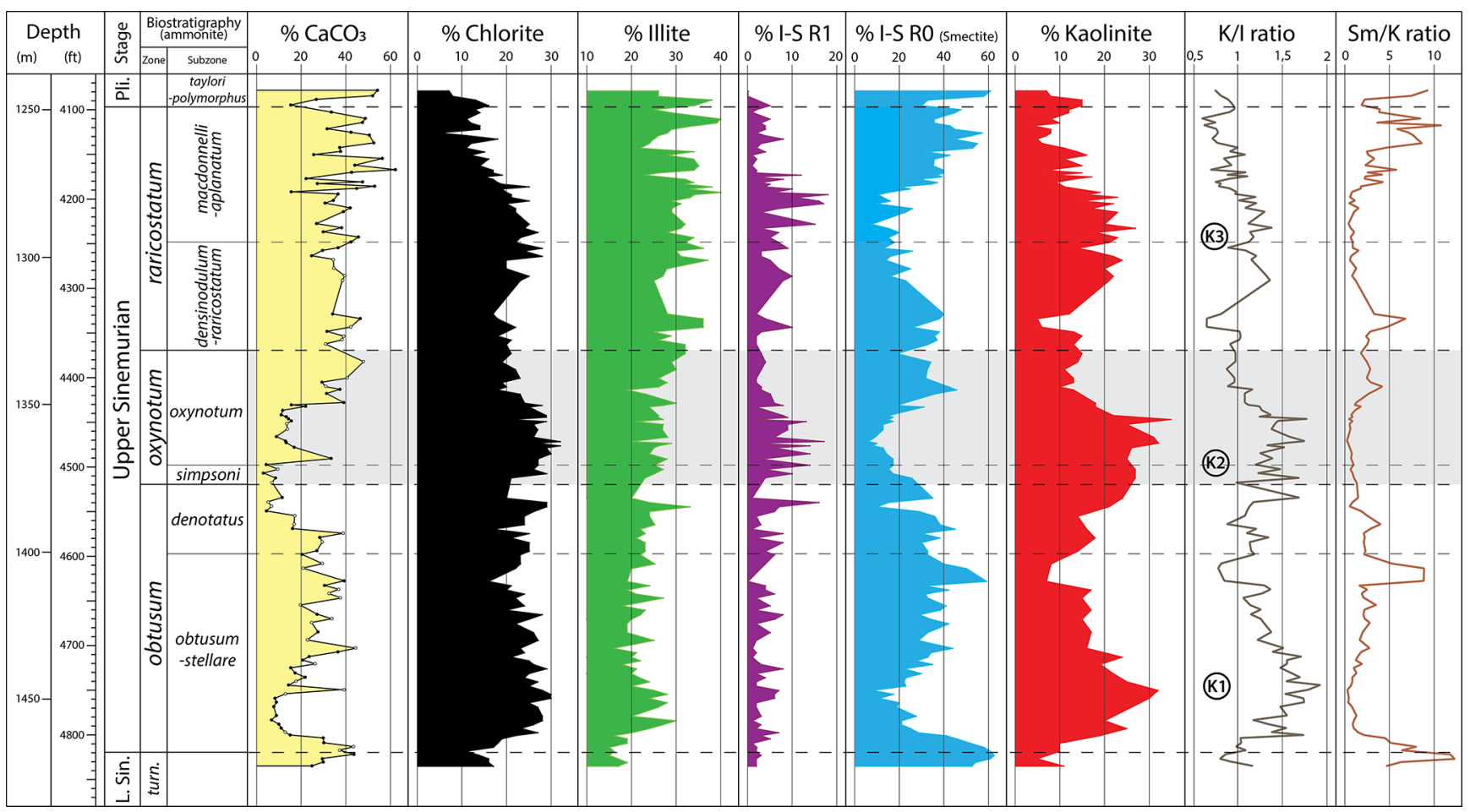

Figure 5. Calcite proportions and composition of the clay fraction of the upper Sinemurian strata of the Mochras borehole. Kaolinite / illite $(\mathrm{K} / \mathrm{I})$ and smectite / kaolinite $(\mathrm{Sm} / \mathrm{K})$ ratios correspond to the ratio of the areas of the main peaks of these minerals. L. Sin. - lower Sinemurian, Pli. - Pliensbachian, turn. = turneri.

raricostatum zones, while a decreasing trend is observed in the raricostatum zone to the base of the Pliensbachian.

\section{Discussion}

\subsection{Diagenetic influence}

\subsubsection{Influence of diagenesis on clay mineral assemblages}

The use of clay minerals as climatic proxies assumes that these minerals are mainly of detrital origin. However, the increase in temperature associated with burial may trigger various transformations of detrital clay minerals to change the constitution of detrital clay assemblages. In fine-grained clayey and marly sediments, among the possible transformations, the illitisation of smectite is certainly the most important. The illitisation of smectite into R1-type illite-smectite mixed layers begins when the temperatures reach $60-70{ }^{\circ} \mathrm{C}$ at a depth of burial of the order of $2000 \mathrm{~m}$, considering a normal geothermal gradient (Šucha et al., 1993; Lanson et al., 2009; Dellisanti et al., 2010).

The occurrence of abundant smectite in the Sinemurian strata in the Mochras borehole and the presence of a smectiterich interval in the Montcornet borehole indicate a limited diagenetic influence due to the relatively shallow depth of burial. In both boreholes, the maximum burial temper- atures probably never exceeded $70^{\circ} \mathrm{C}$, which is consistent with the geological history of the Cardigan Bay and Paris basins. In the Cardigan Bay Basin, the thickness of the sediments overlying the Sinemurian can be estimated to be $\sim 1400 \mathrm{~m}$ including $800 \mathrm{~m}$ of Lower Jurassic and $\sim 600 \mathrm{~m}$ of Oligo-Miocene and Quaternary sedimentary rocks, with any of the younger Mesozoic strata eroded before deposition of the Cenozoic sediments (Tappin et al., 1994; Holford et al., 2005). The negligible influence of burial diagenesis is also confirmed by the occurrence of immature to only marginally mature organic matter $(\mathrm{OM})$ revealed by RockEval pyrolysis data from the Sinemurian mudrocks (van de Schootbrugge et al., 2005; Storm et al., 2020). In the Sinemurian succession, $T_{\max }$ values ranging between 423 and $436^{\circ} \mathrm{C}$ (average $428^{\circ} \mathrm{C}, n=195$; Storm et al., 2020) indicate immature $\mathrm{OM}$ or occasionally early mature $\mathrm{OM}$ at the onset of the oil window. Vitrinite reflectance $\left(\mathrm{R}_{0} \max \right)$ data suggest a higher maximal burial temperature of the Sinemurian strata (Corcoran and Clayton, 1999) ranging between 83 and $90^{\circ} \mathrm{C}$ (Holford et al., 2005), but the authors discarded the lowest values of $\mathrm{R}_{0}$ (low burial temperatures), considering that these data were not reliable enough. Such high temperatures are incompatible with both the occurrence of smectite and with the presence of immature organic matter, and therefore we consider the low values of vitrinite reflectance data published by Holford et al. (2005) to be fully realistic. 


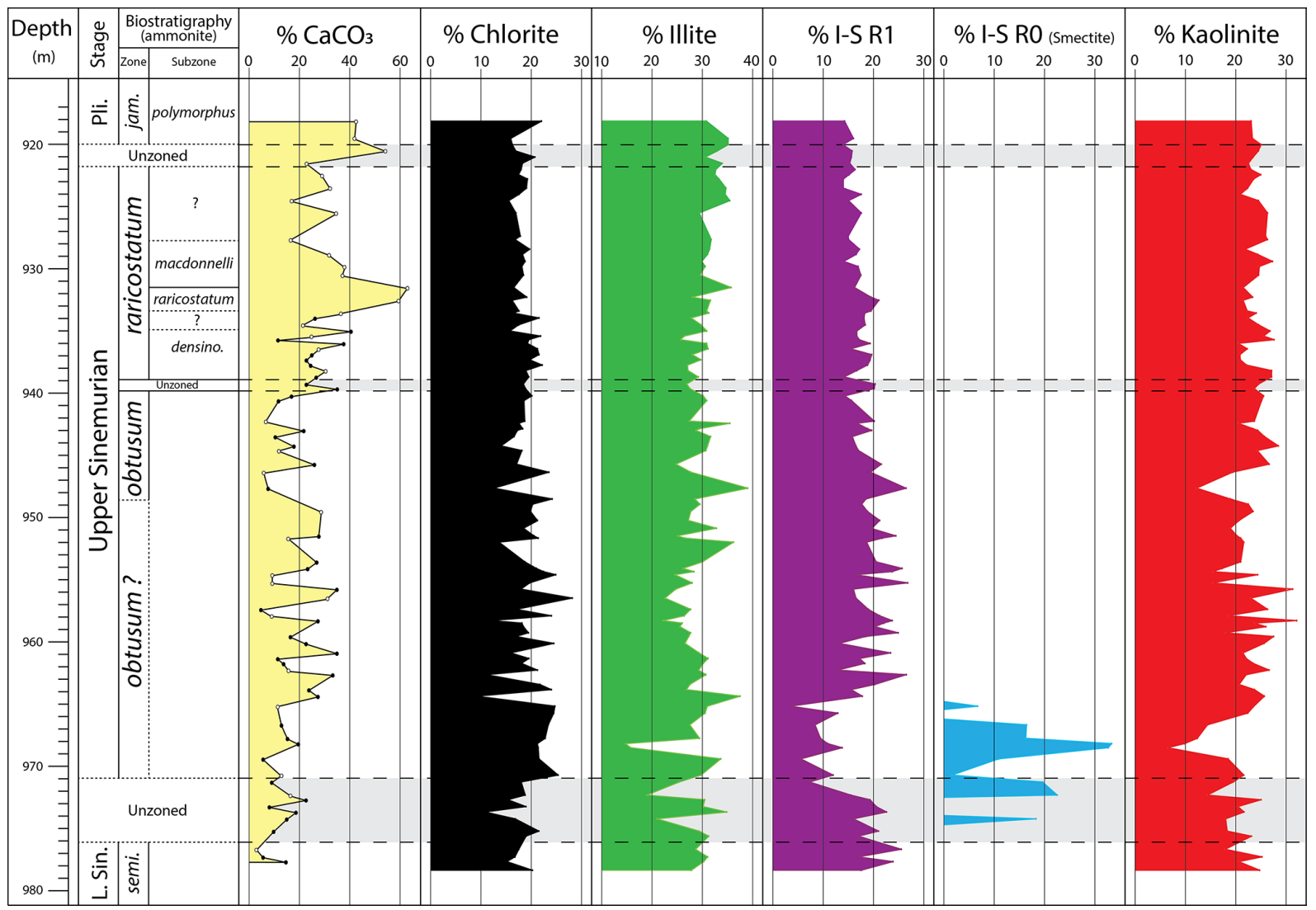

Figure 6. Calcite proportions and composition of the clay fraction of the upper Sinemurian strata of the Montcornet borehole. Abbreviations: densinod. - densinodulum, macdonn. - macdonnelli, Pli. - Pliensbachian, polymor - polymorphus, raricost. - raricostatum.

In the Montcornet borehole, the depth of burial of the upper Sinemurian can be estimated at a maximum of $\sim 2000 \mathrm{~m}$, including the entire Jurassic succession $(870 \mathrm{~m}), \sim 200 \mathrm{~m}$ of Cenomanian and Turonian chalks, and now eroded and/or dissolved Coniacian to Maastrichtian chalks. The Coniacian to Campanian chalk is $\sim 400 \mathrm{~m}$ thick in the central Paris Basin (southwest of Paris; Robaszynski et al., 2005), but the uppermost Campanian and Maastrichtian deposits were eroded, and therefore the thickness of the entire Upper Cretaceous is difficult to estimate. To the east of the Paris Basin, a maximum thickness of the chalk deposits is estimated as only around $200 \mathrm{~m}$ (Blaise et al., 2014). According to the apatite fission-track thermochronology study of Barbarand et al. (2018), the entire Cretaceous deposits would have a thickness of $1000 \mathrm{~m}$, which seems to be a maximum value. Assuming a total burial depth of $2000 \mathrm{~m}$, which probably represents a maximum, the burial-temperature rise probably did not exceed $60^{\circ} \mathrm{C}$, which is consistent with the preservation of smectite. This is also confirmed by $T_{\max }$ values, which range between 423 and $426^{\circ} \mathrm{C}$ in the Sinemurian of the Montcornet borehole, indicating that organic matter is still immature (Disnar et al., 1996; Mercuzot et al., 2020).

Clay diagenesis can be also revealed by relationships between clay mineralogy and the lithology, notably in marl- limestone alternations (Deconinck and Debrabant, 1985; Deconinck, 1987; Levert and Ferry, 1988), but in the two studied boreholes, there is no statistically strong correlation between $\mathrm{CaCO}_{3}$ content and the proportion of each clay species (Fig. 9). As an example, in the Mochras borehole, the proportion of smectite is weakly correlated with the percentages of $\mathrm{CaCO}_{3}(r=0.31, n=128, p$ value $<0.05)$, which is evidence against the better preservation of smectite in carbonate-rich intervals.

The occurrence of authigenic well-crystallised kaolinite can also be envisaged, as it was previously observed in some porous carbonates in the upper Pliensbachian of the Paris Basin (e.g. Bougeault et al., 2017). However, this phase can be easily highlighted on diffractograms by the presence of very narrow peaks, indicating good crystallinity, which is not the case here, thus excluding the occurrence of measurable authigenic kaolinite. Moreover, sampling of porous limestones has been avoided.

Contrary to what has been observed in the overlying Pliensbachian strata of the Mochras borehole, we do not identify in the upper Sinemurian any authigenic mineral such as clinoptilolite or berthierine (Deconinck et al., 2019). Consequently, we infer that most clay minerals identified in the 


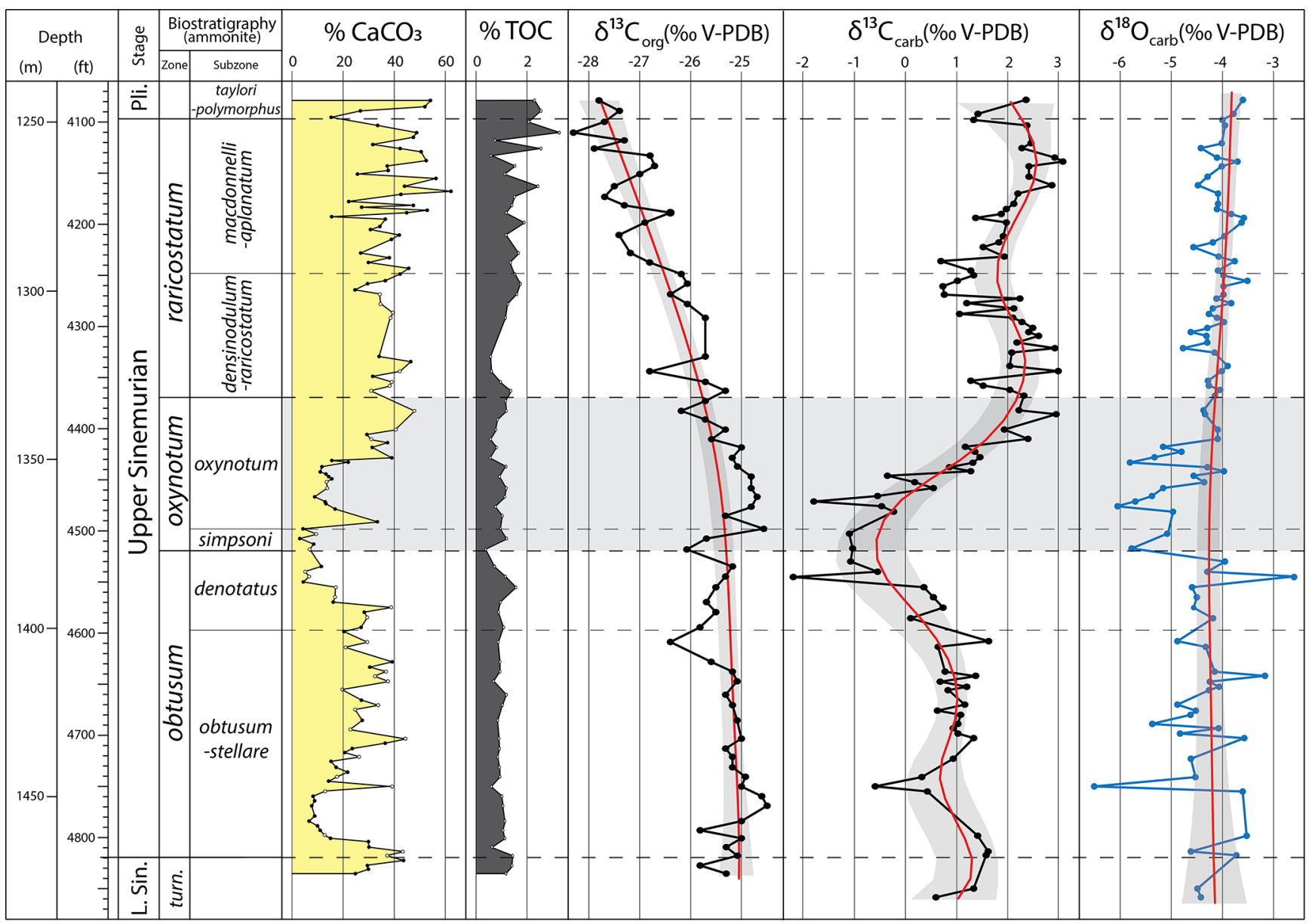

Figure 7. Carbon $\left(\delta^{13} \mathrm{C}_{\text {carb }}\right.$ and $\left.\delta^{13} \mathrm{C}_{\mathrm{org}}\right)$ and oxygen $\left(\delta^{18} \mathrm{O}_{\text {carb }}\right)$ isotopes of the upper Sinemurian in the Mochras borehole coupled with the proportions of $\mathrm{CaCO}_{3}$ and TOC. The smoothing curve is in red, and the $95 \%$ confidence interval is in grey (kernel regression). L. Sin. lower Sinemurian, Pli. - Pliensbachian, turn. - turneri.

Sinemurian of the two studied boreholes are dominantly detrital and do carry climatic and environmental information.

\subsubsection{Impact of diagenesis on isotopic data}

Fluid circulations and temperature may disturb the primary isotope signal in sediment during late diagenesis, notably for the bulk carbonate signal (Anderson, 1969; Hudson, 1977; Marshall, 1992). Early diagenesis may also impact the isotope signal from bulk carbonate when low calcium carbonate content is present (Ader and Javoy, 1998; Bougeault et al., 2017).

$\delta^{18} \mathrm{O}$ values are more sensitive to fluid circulation and recrystallisation, particularly in porous rocks, normally leading to more negative and/or scattered values (e.g. Hudson, 1977; Marshall, 1992; Stoll and Schrag, 2000). Although the low porosity and permeability of clayey limestones, marls, and claystones of the Mochras and Montcornet boreholes are not favourable to fluid circulation, some diagenetic features such as the occurrence of nodular beds and distinct cal- cite and siderite nodules, suggest that isotopic values may be locally significantly altered by diagenetic processes. In the Montcornet borehole, this is the case in the underlying Hettangian succession where the secondary crystallisation of calcite in sulfate-reducing environments is responsible for a depletion in ${ }^{13} \mathrm{C}$ (Ader and Javoy, 1998). In the overlying Pliensbachian strata of this borehole, an alteration of the $\delta^{13} \mathrm{C}_{\text {carb }}$ was also observed by Bougeault et al. (2017), notably in a carbonate-depleted interval $(<10 \%$ $\mathrm{CaCO}_{3}$ ) with common siderite and calcite nodules, suggesting a migration of carbonate within clayey series. An interval with similar characteristics (clay-rich strata with common carbonate concretions, traces of siderite) is present in the obtusum-oxynotum zone transition in the Mochras borehole (Woodland, 1971). The significant correlation $(r=0.68, n=$ 96, $p$ value $<0.05$ ) between the carbonate content and the $\delta^{13} \mathrm{C}_{\mathrm{carb}}$ values could reflect the disturbance of the inorganic carbon signal $\left(\delta^{13} \mathrm{C}_{\text {carb }}\right)$ in such a clayey interval more sensitive to diagenesis (Fig. 9). A disturbance of the isotopic signal of carbon and oxygen from carbonates in this more clayey 


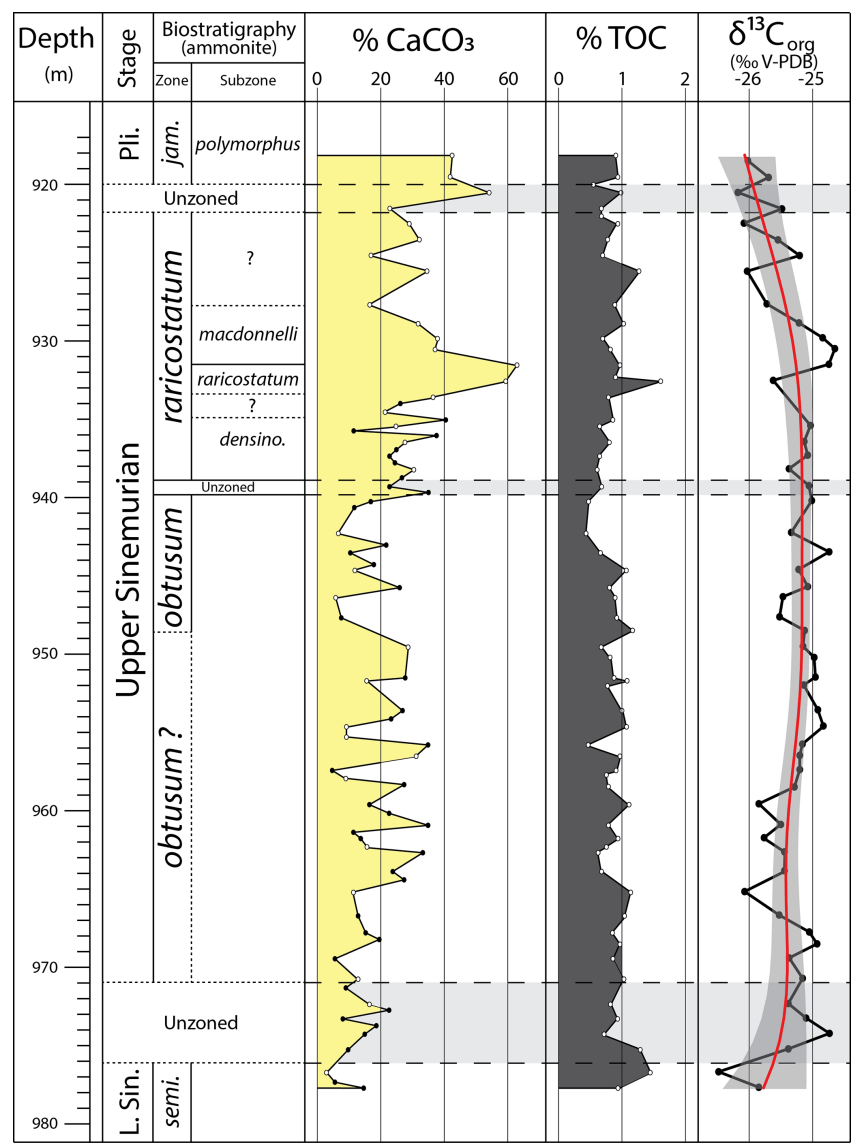

Figure 8. Carbon isotopic ratio $\left(\delta^{13} \mathrm{C}_{\mathrm{org}}\right)$ of the upper Sinemurian strata of the Montcornet borehole coupled to $\mathrm{CaCO}_{3}$ and TOC proportions. The smoothing curve is in red, and the $95 \%$ confidence interval is in grey (kernel regression). Abbreviations: densinod. densinodulum, L. Sin. - lower Sinemurian, macdonn. - macdonnelli, Pli. - Pliensbachian, polymor - polymorphus, raricost. - raricostatum, semi. - semicostatum.

interval (1352.4 to $1393.6 \mathrm{~m}$ ) is likely, especially when measurements taken from the carbon of organic matter $\left(\delta^{13} \mathrm{C}_{\mathrm{org}}\right)$ and macrofossils do not show parallel variations (see Fig. 7 and Ullmann et al., 2021).

Long-distance correlations can be made based on the comparison of $\delta^{13} \mathrm{C}_{\text {org }}$ fluctuations through the Lower Jurassic in several sedimentary basins, likely reflecting a primary signal (Storm et al., 2020), even if diagenetic impacts on organic compounds may be locally significant (Meyers, 1994; Lehmann et al., 2002). Figure 10 allows a comparison of the $\delta^{13} \mathrm{C}_{\text {org }}$ signal obtained from basins in the UK-France area and shows a consistent carbon isotopic signal based on organic matter, highlighting a slight carbon isotope negative excursion (OO-CIE) at the obtusum-oxynotum zone transition and the marked negative carbon isotope excursion of the Sinemurian-Pliensbachian boundary (SPBE). Consequently, in the case of the Mochras and Montcornet boreholes, only $\delta^{13} \mathrm{C}_{\text {org }}$ is a reliable proxy to constrain carbon cycle per- turbations during the late Sinemurian, while $\delta^{13} \mathrm{C}_{\text {carb }}$ and $\delta^{18} \mathrm{O}$ signals of bulk rock cannot be interpreted confidently in terms of environmental and climatic fluctuations.

\subsection{Environmental significance of clay mineral assemblages}

\subsubsection{Detrital sources of clay minerals}

Although clay minerals may be transported over long distances, the Welsh High and the Irish Massif were likely the main detrital sources of the Cardigan Bay Basin (Dobson and Whittington, 1987; Xu et al., 2018). In the coeval deposits of the Dorset coast, southern England, the clay assemblages show a similar composition, but smectite is less abundant, suggesting that detrital inputs into the Wessex Basin originated from distinct detrital sources including the Cornubian and Armorican massifs (Schöllhorn et al., 2020a). In the Paris Basin, the main detrital sources of clay minerals were probably the proximal Paleozoic massifs, including the London-Brabant Massif (LBM), the Armorican Massif, and the Massif Central (Müller et al., 1973; Debrabant et al., 1992; Thierry et al., 2000), as suggested by dominant continental organic matter preserved in the Jurassic sediments drilled at Montcornet (Disnar et al., 1996).

The abundance of illite and chlorite reflects the intensity of erosion of these continental areas. Precambrian and/or Paleozoic mudrocks from the Welsh High and from the LBM mainly contain mica-illite, chlorite, and corrensite (regular chlorite-smectite mixed layer), reflecting deep burial and low-grade metamorphism (Lefrançois et al., 1993; Han et al., 2000; Merriman, 2006; Hillier et al., 2006). These assemblages occur in most Variscan massifs in Europe, and as a result, the high proportions of chlorite and illite in most Jurassic sedimentary successions of northwestern Europe mostly reflect the erosion of these Paleozoic and older rocks (Jeans et al., 2001). In the Mochras borehole, from the base to the top of the upper Sinemurian, the proportions of illite increase from ca. $20 \%$ to $35 \%$. This evolution suggests that during the late Sinemurian, an increasing erosion of the Welsh High basement occurred compared to the development of thick soils. This may be the consequence of a long-term uplift of the Welsh High aided by faulting. By comparison, the constant proportions of illite recorded in the Montcornet borehole, located proximately south of the LBM, suggest continuous unchanged processes of erosion on this tectonically stable massif.

In sediments, smectites have various origins. These minerals are most often reworked from soils where they formed under a warm and seasonally humid climate (Chamley, 1989). However, smectite can also be formed in marine environments either at the expense of volcanic glass or as an authigenic phase in slowly deposited sediment (Deconinck and Chamley, 1995). The Sinemurian strata from the Mochras borehole do not show any evidence of volcanic origin and 

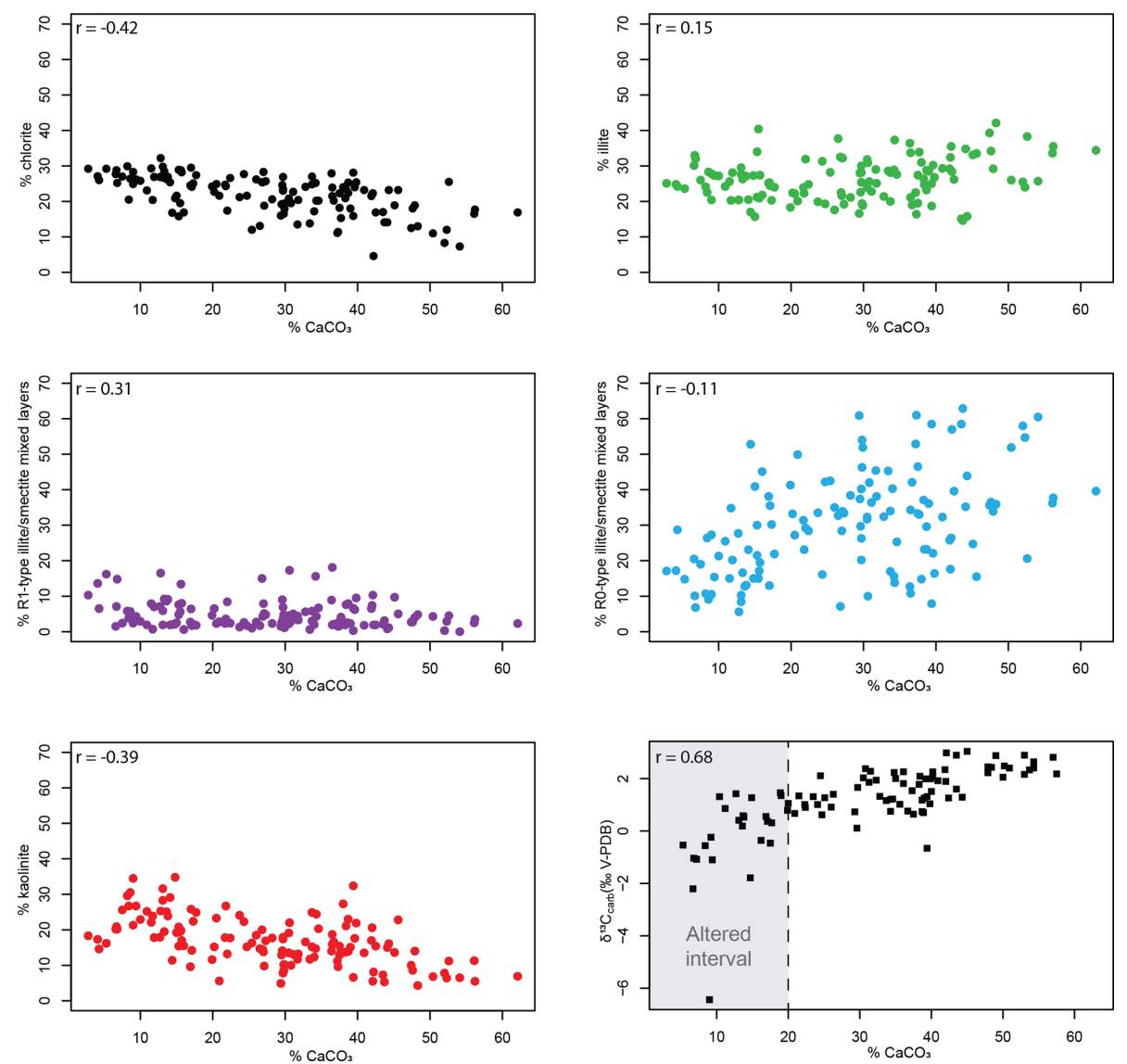

Figure 9. Correlations between $\mathrm{CaCO}_{3}$ content, the clay mineral relative proportions in the clay fraction, and $\delta^{13} \mathrm{C}_{\mathrm{carb}}$ values in the Mochras borehole.

were rapidly deposited, with high sedimentation rates responsible for their particularly high thickness $(220 \mathrm{~m}$ for the upper Sinemurian). The duration of the upper Sinemurian is estimated at $3 \mathrm{Myr}$, which suggests an average sedimentation rate (after compaction) of more than $70 \mathrm{~m} \mathrm{Myr}^{-1}$ (Storm et al., 2020). In the macdonnelli-aplanatum subzones, a high mean sedimentation rate of ca. $40 \mathrm{~m} \mathrm{Myr}^{-1}$ can be estimated considering a duration of about $800 \mathrm{kyr}$ for these subzones according to cyclostratigraphical studies (Ruhl et al., 2016). These relatively high sedimentation rates are not favourable to smectite authigenesis, and consequently, most smectite minerals identified here are likely detrital and originated from pedogenic blankets developed over the Welsh or Irish massifs during periods of warm and seasonally humid climate.

Kaolinite, as for illite and chlorite, can be reworked from kaolinite-bearing sedimentary rocks and from the palaeoweathering profile in continental areas (Hurst, 1985). Kaolinite may be reworked from sandstones where its authigenic formation is common as pore-filling booklets, such as Devonian (Old Red Sandstone) and Carboniferous sandstones from southern England and Wales (Hillier et al., 2006; Shaw, 2006; Spears, 2006). Kaolinite may also originate from soils formed under a hot and regularly humid climate (Chamley, 1989; Ruffell et al., 2002). In both cases, increasing proportions of kaolinite in a sedimentary succession suggest enhanced runoff, favouring erosional processes and/or a hydrolysing climate.

\subsubsection{Environmental control of clay sedimentation}

In the Mochras borehole, the clay mineralogy of the upper Sinemurian is relatively similar to that observed in the overlying Pliensbachian formations, where there is an inverse relationship in the relative proportions of smectite and kaolinite. The alternation of kaolinite-rich and smectite-rich intervals was interpreted for the Pliensbachian to be the result of climate fluctuations respectively dominated by regularly humid periods and semi-arid conditions (Deconinck et al., 2019). This climate mode seems to be established at least at the beginning of the late Sinemurian on the Welsh High and the surrounding massifs. In the northern Paris Basin, in the Montcornet borehole, such climatic fluctuations are not recorded, even though this basin was located at a palaeolatitude comparable to the Cardigan Bay Basin. Apart from the smectite-rich interval occurring at the transition between the 


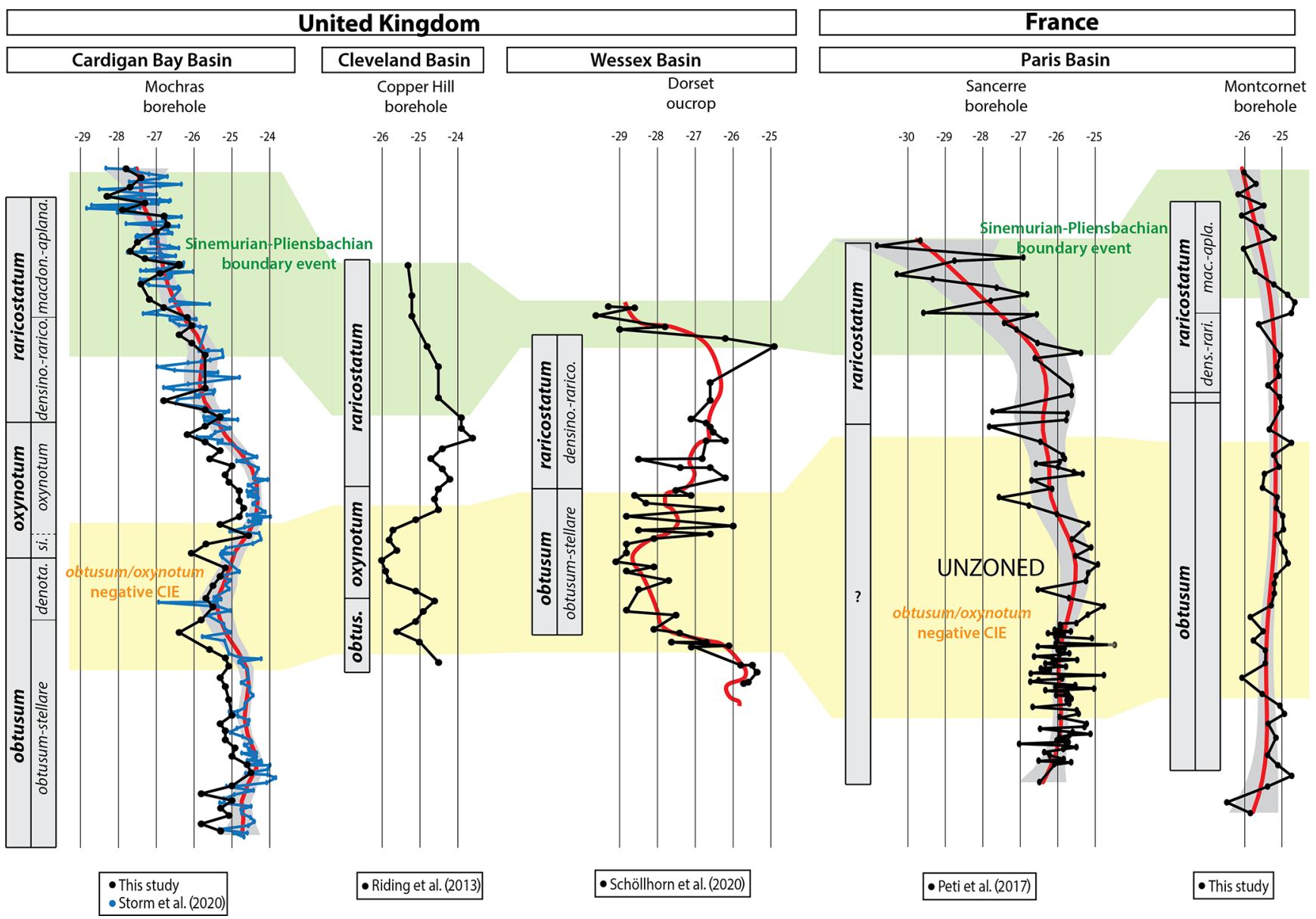

Figure 10. Correlation of the negative excursion of $\delta^{13} \mathrm{C}_{\text {org }}$ during the upper Sinemurian in Cardigan Bay Basin (this study; Storm et al., 2020), Cleveland Basin (Riding et al., 2013), Wessex Basin (Schöllhorn et al., 2020a) and Paris Basin (this study; Peti et al., 2017).

lower and the upper Sinemurian and at the base of the $o b$ tusum zone, the clay mineralogy is rather uniform. In this borehole, such smectite-rich intervals referred to as "smectite events" were also recorded in the Pliensbachian sediments (Bougeault et al., 2017). The occurrence of these smectite events was interpreted as the result of the lowering of the sea level, favouring the formation of smectite in soils developed on newly exposed lands of the LBM as also observed during the Middle-Late Jurassic period (Pellenard and Deconinck, 2006; Hesselbo et al., 2009). The lower-upper Sinemurian boundary and the base of the obtusum zone precisely coincided with relative sea level lowstands in the northwestern European domain (Jacquin et al., 1998; Hesselbo 2008; Haq, 2018). Therefore, the smectite-rich interval occurring in the Sinemurian of Montcornet is also interpreted as a consequence of the lowering of the sea level, allowing the formation of smectite on newly exposed lands of the LBM with its comparatively subdued relief. By contrast, during relative sea level highstand, the LBM was probably at least partly flooded, suggesting that this massif was already deeply eroded and relatively flat as early as the Sinemurian. A sim- ilar behaviour of this massif regarding sea level fluctuations lasted until the Late Jurassic (Hesselbo et al., 2009). Consequently, with the LBM often being submerged, it is probable that the clay minerals deposited to the south of this massif had a partly more distant origin, and this may explain the difference from the Cardigan Bay Basin. The sea level highstand during the oxynotum zone is likely responsible for the starvation of the northern part of the Paris Basin, with a reduced sedimentation rate and even the significant sedimentary gap equally observed on the Dorset coast (see Hallam, 1999, 2000; Coe and Hesselbo, 2000; Hesselbo et al., 2020).

\subsubsection{Kaolinite-rich intervals - Mochras borehole}

The three kaolinite-rich intervals observed in the Mochras borehole are highlighted by the kaolinite / illite and smectite / kaolinite ratios (K/I and Sm/K, respectively; Fig. 11). These intervals occur (1) at the base of the obtusum zone (interval K1), (2) around the boundary between the obtusum and oxynotum zones (interval K2), and (3) in the raricostatum zone (interval K3). The onset of a fourth kaolinite-rich 
interval is present at the Sinemurian-Pliensbachian boundary and lasted through to the lower part of the jamesoni zone (Deconinck et al., 2019).

These intervals may be associated with more humid conditions, but they occur in different tectonic and eustatic settings. K1 occurs during a period of lowstand of the sea level (Hesselbo, 2008). These conditions may have enhanced the proportions of kaolinite since this mineral is well-known to be deposited preferentially in proximal environments due to differential settling processes of clay minerals (Gibbs, 1977; Godet et al., 2008). Therefore, we suggest that the high proportions of kaolinite could be the result of combined influences of a more humid climate and low relative sea level conditions. By contrast, $\mathrm{K} 2$ occurs during a period of a high sea level, favourable to the deposition of more smectite. Consequently, as this kaolinite-rich interval is also the most prominent, it is probable that the climatic conditions were particularly hydrolysing (wet and/or warm) from the upper part of the obtusum zone to the lower part of the oxynotum zone. The resulting significant detrital fluxes were probably responsible for a dilution of the carbonates, leading to a more clay-rich sedimentation during this interval. The proportions of kaolinite in $\mathrm{K} 3$ are lower than in $\mathrm{K} 1$ and $\mathrm{K} 2$, and this interval is also marked by the relative abundance of illite, suggesting more efficient erosion of the basement that may be linked to tectonic influences. It is therefore possible that in $\mathrm{K} 3$, kaolinite may be partly reworked together with illite from the unmetamorphosed rocks of the basement.

Interestingly, the three kaolinite-rich intervals seem to coincide with higher values of the ${ }^{87} \mathrm{Sr} /{ }^{86} \mathrm{Sr}$ ratio, consistent with increasing detrital influences linked to the acceleration of the hydrological cycle (Fig. 10). The most prominent increase in the ${ }^{87} \mathrm{Sr} /{ }^{86} \mathrm{Sr}$ ratio precisely coincides with the most prominent increase in kaolinite (K2) that occurs around the transition between the obtusum and the oxynotum zones. It also coincides with the increase in chemical weathering expressed by the CIA (chemical index of alteration) and clay mineralogy observed in Dorset (Schöllhorn et al., 2020a). It should be noted, however, that the fluctuations in the ${ }^{87} \mathrm{Sr} /{ }^{86} \mathrm{Sr}$ ratio correspond to a global signal, while the clay minerals register a local signal, and that the $\mathrm{Sr}$ isotope fluctuations are based on very few and widely spaced data points.

To summarise, the three kaolinite-rich intervals are indicative of increasing moisture. Of these, $\mathrm{K} 2$ occurring in the uppermost part of the obtusum zone and the lower part of the oxynotum zone is of particular interest, as it is at least indicative of a significant acceleration of the hydrological cycle. In the Copper Hill borehole drilled close to Ancaster in Lincolnshire, eastern England, this interval is characterised by an increase in Classopollis, also indicating a warm climate, and by a negative excursion of $-2 /-3 \%$ of $\delta^{13} \mathrm{C}_{\text {org }}$ (Riding et al., 2013). Surprisingly, this negative excursion is less clearly recorded in organic carbon at Mochras (Fig. 10; van de Schootbrugge et al., 2005; Storm et al., 2020).

\subsection{Carbon cycle evolution and SPBE record}

A net decrease in the $\delta^{13} \mathrm{C}_{\text {org }}$ values initiated from the late oxynotum zone and the early raricostatum zone, culminating in a marked negative excursion of $\delta^{13} \mathrm{C}_{\text {org }}$ near the Sinemurian-Pliensbachian boundary, is clearly observed at the two sites (Fig. 10). The amplitude of the decrease reaches $-1 \%$ ( $-25 \%$ to $-26 \%$ ) in the Paris Basin and $-3 \%$ o $(-25 \%$ o to $-28 \%$ o in the Cardigan Bay Basin, confirming the negative shift highlighted by Storm et al. (2020). The condensation or even a significant hiatus in the northern part of the Paris Basin at the Sinemurian-Pliensbachian partly shortens this excursion and is therefore likely responsible for the difference in the amplitude of the negative excursion recorded at the two sites (Bougeault et al., 2017; Mercuzot et al., 2020). This decrease is equally recorded in the Sancerre borehole in the southern Paris Basin (Figs. 1, 10) from the early raricostatum zone and shows an amplitude of $-4 \%$ (Peti et al., 2017). The environmental significance of this pronounced shift can be addressed, as it likely corresponds to the SPBE, which was apparently recognised later at the beginning of the early Pliensbachian (jamesoni zone) in Robin Hood's Bay from $\delta^{13} \mathrm{C}_{\text {wood }}$ and $\delta^{13} \mathrm{C}_{\text {carb }}$ data (Jenkyns et al., 2002; Korte and Hesselbo, 2011) and estimated with a duration of $2 \mathrm{Myr}$ on the basis of cyclostratigraphical analyses performed on the Mochras core (Ruhl et al., 2016). Since stratigraphic evolution of the $\delta^{13} \mathrm{C}_{\text {org }}$ could be due to local changes in the type of organic matter (Suan et al., 2015), evolution of the type of OM has to be discussed here. No change was reported in the upper Sinemurian deposits of Mochras according to van de Schootbrugge et al. (2005), who highlight a dominant continental type. Similar conclusions arise from the study of organic matter preserved in the Montcornet borehole (Disnar et al., 1996). However, recent data on OM from Mochras show higher hydrogen index (HI) values during the SPBE (Storm et al., 2020). This suggests that the negative excursion of the SPBE could be enhanced by an increase in marine organic matter. The effect of a change in the type of OM cannot, however, solely explain the observed trend, as the carbon isotope signal from macrofossil wood shows the same evolution (Storm et al., 2020). These observations suggest that volcanic activity and hydrothermalism linked to a potential late phase of the CAMP, notably through the opening of the Hispanic Corridor, have likely favoured a progressive and long-term input of ${ }^{12} \mathrm{C}$ in both atmospheric and ocean reservoirs (Price et al., 2016; Ruhl et al., 2016).

This negative carbon excursion from the raricostatum zone is also well-recorded in the $\delta^{13} \mathrm{C}_{\text {carb }}$ signal in the Montcornet borehole (Bougeault et al., 2017; Mercuzot et al., 2020). Surprisingly, it is not prominent in the carbonate record at Mochras, where a negative shift is recorded later at the beginning of the Pliensbachian (Ruhl et al., 2016). The discrepancy between the two isotopic signals $\left(\delta^{13} \mathrm{C}_{\mathrm{carb}}\right.$ and $\delta^{13} \mathrm{C}_{\text {org }}$ ) in the Mochras borehole could be due to local diagenetic effects that overprint the primary signal of car- 


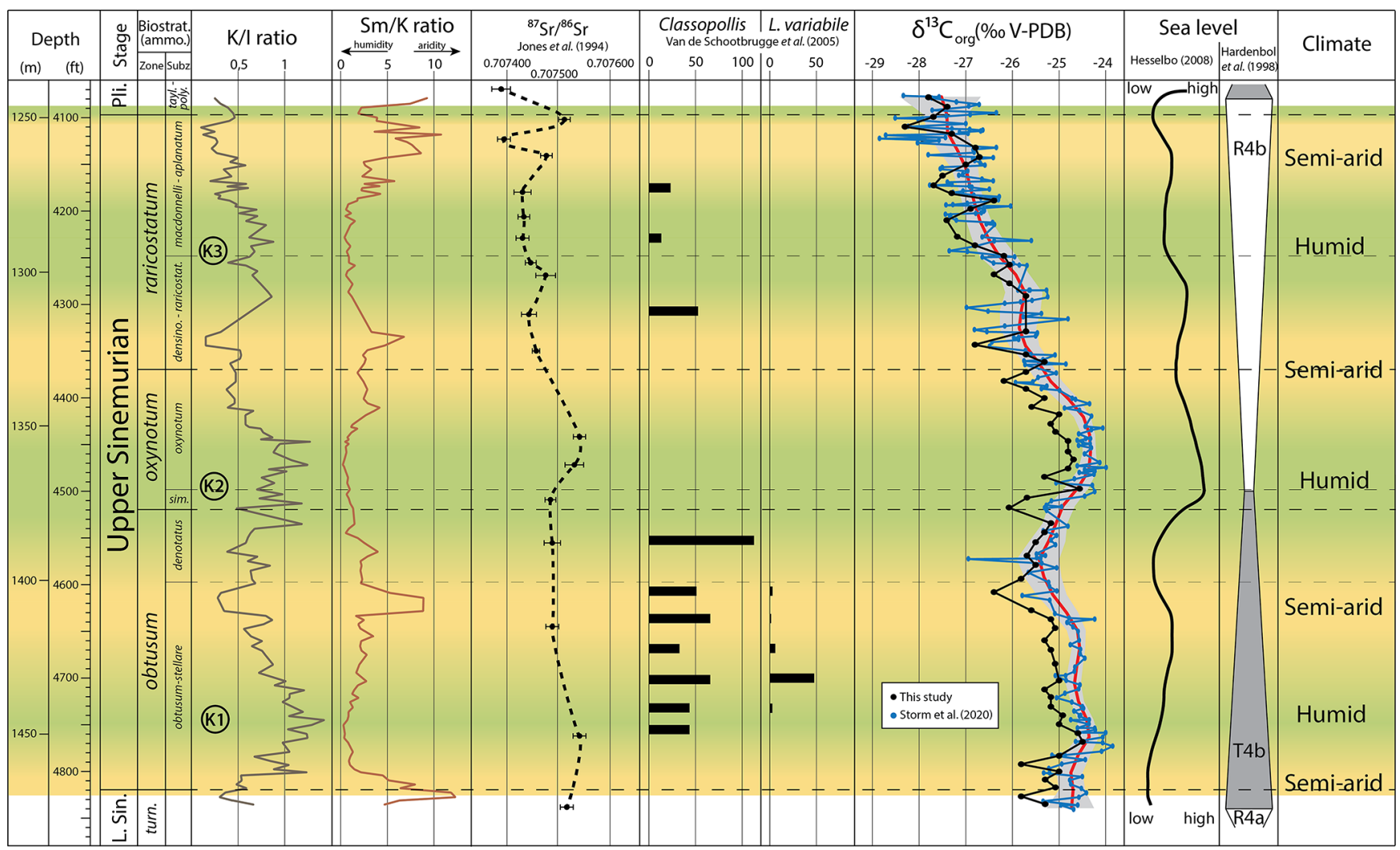

Figure 11. Palaeoclimatic interpretations inferred from clay mineral assemblages expressed by K/I and Sm/K ratios compared with Classopollis and Liasidium variabile abundance and strontium isotopes (Jones et al., 1994; van de Schootbrugge et al., 2005; Riding et al., 2013), as well as carbon isotope variations (this study; Storm et al., 2020). Eustatic and/or regional relative sea level variations are from Hardenbol et al. (1998) and Hesselbo (2008).

bonates, as is probably also the case for the oxynotum zone. Thus, the onset of the SPBE is clearly recognised from the early raricostatum zone, while the shift reaches a maximum during the jamesoni zone (plateau of low $\delta^{13} \mathrm{C}_{\text {org }}$ values; Storm et al., 2020) resulting from a long and progressive increase in light carbon release in relation to volcanic activity. Some authors (Mercuzot et al., 2020; Schöllhorn et al., 2020a, b) previously mentioned such differences in the onset and record of the SPBE identified in various basins worldwide, which may express local diagenetic and environmental effects. This may explain why the runoff conditions, supported in this study by the kaolinite content, first decrease (i.e. raricostatum zone) before drastically increasing during the jamesoni zone (Deconinck et al., 2019), which should correspond to the maximal disturbance in the carbon cycle concomitant with warmer temperatures and enhanced rainfall. This relationship between an increase in kaolinite content and a negative carbon isotope signal seems specific to the SPBE and likely due to the impact of volcanism that triggered both temperature and moisture increase and ${ }^{12} \mathrm{C}$ input. Indeed, the inverse relationship is observed earlier in the Sinemurian for which periods of high kaolinite content (i.e. K1 and K2) are mostly correlated with positive car- bon isotope shifts (Fig. 11). Such a response could be explained under normal conditions by increased runoff, which can promote the supply of continental organic matter from land masses and better preservation during these wet periods.

\section{Conclusions}

The study of the clay mineralogy in the upper Sinemurian of the Mochras and Montcornet boreholes shows that the clay minerals are mainly detrital and come from the erosion of the basement and the soil cover of the Paleozoic massifs. The thick and continuous succession penetrated by the Mochras borehole shows significant fluctuations in the relative proportions of clay minerals. The successions shows an inverse relationship between the proportions of kaolinite and smectite, which probably results from an alternation of warm and humid periods with semi-arid periods. This climatic mode previously identified in the overlying Pliensbachian therefore seems to be in place at least from the late Sinemurian. The end of the obtusum zone and the oxynotum zone corresponds to a particularly hot and humid period favourable to strong runoff and significant terrigenous inputs probably responsible for a repression of carbonate sedimentation. This partic- 
ular hot and humid interval is also expressed by the abundances of Classopollis and Liasidium variabile, as well as by an overall slight positive excursion of $\delta^{13} \mathrm{C}_{\mathrm{org}}$.

In the Montcornet borehole to the north of the Paris Basin, the thinner succession has many hiatuses, notably that of the oxynotum zone. The clay minerals are similar to those identified in the Cardigan Bay Basin, but the discontinuous series does not allow the alternation of humid and semi-arid periods to be identified. It is possible that this also results from the different and more distant origin of clays. In this borehole, a smectite-rich interval is identified within the obtusum zone during a period of lowstand of sea level. This smectite interval, like those identified in the overlying Pliensbachian, would result from the emergence of the London-Brabant Massif then subjected to active pedogenesis. A eustatic control of the clay sedimentation is therefore expressed along the London-Brabant Massif, a situation previously proposed for the Pliensbachian which lasted until the end of the Jurassic.

Unlike the clay diagenesis, which is negligible, carbonate diagenesis notably expressed as nodules causes a dispersion of the isotopic values of $\delta^{13} \mathrm{C}_{\mathrm{carb}}$ and $\delta^{18} \mathrm{O}$ whose interpretation in terms of palaeotemperature is unsound. The evolution of $\delta^{13} \mathrm{C}_{\mathrm{org}}$ reveals a progressive decrease from the raricostatum zone before the very low values at the SinemurianPliensbachian transition characterising the SPBE.

Data availability. Data are available on request to the authors.

Author contributions. All authors contributed to the interpretation of the data and approved the submitted version. TM, JFD, and PP wrote the paper with inputs from SPH, JBR, CVU, CB, MM, ALS, EH, and PL. TM, JFD, and PP realised mineralogical analyses. CVU and ALS realised geochemical analyses. SPH, JBR, CB, and $\mathrm{MM}$ contributed to sedimentological descriptions of the boreholes.

Competing interests. The authors declare that they have no conflict of interest.

Disclaimer. Publisher's note: Copernicus Publications remains neutral with regard to jurisdictional claims in published maps and institutional affiliations.

Acknowledgements. The authors warmly thank Jean-Louis Dommergues, who determined ammonites newly collected during the description and sampling of the Montcornet borehole. We also thank Claude Aurière (Andra) for providing the cores from the A901 borehole. James B. Riding publishes with the approval of the Chief Executive Officer, British Geological Survey (NERC). This is a contribution to the JET (Early Jurassic Earth System and Timescale) Project.
Review statement. This paper was edited by Yves Godderis and reviewed by two anonymous referees.

\section{References}

Ader, M. and Javoy, M.: Diagenèse précoce en milieu sulfuré réducteur: une étude isotopique dans le Jurassique basal du Bassin parisien, Comptes Rendus de l'Académie des Sciences - Series IIA - Earth and Planetary Science, 327, 803-809, https://doi.org/10.1016/S1251-8050(99)80054-8, 1998.

Anderson, T. F.: Self-diffusion of carbon and oxygen in calcite by isotope exchange with carbon dioxide, J. Geophys. Res., 74, 3918-3932, https://doi.org/10.1029/JB074i015p03918, 1969.

Barbarand, J., Bour I., Pagel, M., Quesnel, F., Delcambre, B., Dupuis, C., and Yans, J.: Post-Paleozoic evolution of the northern Ardenne Massif constrained by apatite fission-track thermochronology and geological data, BSGF - Earth Sci. Bull., 189, 16, https://doi.org/10.1051/bsgf/2018015, 2018.

Beccaletto, L., Hanot, F., Serrano, O., and Marc, S.: Overview of the subsurface structural pattern of the Paris Basin (France): Insights from the reprocessing and interpretation of regional seismic lines, Mar. Petrol. Geol., 28, 861-879, https://doi.org/10.1016/j.marpetgeo.2010.11.006, 2011.

Bjerrum, C. J., Surlyk, F., Callomon, J. H., and Slingerland, R. L.: Numerical paleoceanographic study of the Early Jurassic Transcontinental Laurasian Seaway, Paleoceanography, 16, 390404, https://doi.org/10.1029/2000PA000512, 2001.

Blaise, T., Barbarand, J., Kars, M., Ploquin, F., Aubourg, C., Brigaud, B., Cathelineau, M., El Albani, A., Gautheron, C., Izart, A., Janots, D., Michels, R., Pagel, M., Pozzi, J. P., Boiron, M. C., and Landrein, P.: Reconstruction of low temperature $\left(<100^{\circ} \mathrm{C}\right)$ burial in sedimentary basins: a comparison of geothermometer in the intracontinental Paris Basin, Mar. Petrol. Geol., 53, 71-87, https://doi.org/10.1016/j.marpetgeo.2013.08.019, 2014.

Bougeault, C., Pellenard, P., Deconinck, J. F., Hesselbo, S. P., Dommergues, J. L., Bruneau, L., Cocquerez, T., Laffont, R., Huret, E., and Thibault, N.: Climatic and palaeoceanographic changes during the Pliensbachian (Early Jurassic) inferred from clay mineralogy and stable isotope (CO) geochemistry (NW Europe), Global Planet. Change, 149, 139-152, https://doi.org/10.1016/j.gloplacha.2017.01.005, 2017.

Brittain, J. M., Higgs, K. T., and Riding, J. B.: The palynology of the Pabay Shale Formation (Lower Jurassic) of SW Raasay, northern Scotland, Scot. J. Geol., 46, 67-75, https://doi.org/10.1144/0036-9276/01-391, 2010.

Bucefalo Palliani, R. and Riding, J. B.: A palynological investigation of the Lower and lowermost Middle Jurassic strata (Sinemurian to Aalenian) from North Yorkshire, UK, P. Yorks. Geol. Soc., 53, 1-16, https://doi.org/10.1144/pygs.53.1.1, 2000.

Chamley, H.: Clay Sedimentology, Springer Verlag, Berlin, 623 pp., ISBN 978-3-642-85918-8, 1989.

Chandler, M. A., Rind, D., and Ruedy, R.: Pangean climate during the Early Jurassic: GCM simulations and the sedimentary record of paleoclimate, Geol. Soc. Am. Bull., 104, 543-559, https://doi.org/10.1130/00167606(1992)104<0543:PCDTEJ>2.3.CO;2, 1992.

Coe, A. L. and Hesselbo, S. P.: Discussion of Hallam (1999). "Evidence of sea-level fall in sequence stratigraphy: examples from the Jurassic”, Geology, 28, 95-96, 2000. 
Copestake, P. and Johnson, B.: Lower Jurassic Foraminifera from the Llanbedr (Mochras Farm) Borehole, North/Wales, UK, Monograph of the Palaeontographical Society, London, 167, 1403, 2014

Corcoran, D. and Clayton, G.: Interpretation of vitrinite reflectance profiles in the central Irish Sea area: Implications for the timing of organic maturation, J. Petrol. Geol., 22, 261-286, https://doi.org/10.1111/j.1747-5457.1999.tb00987.x, 1999.

Damborenea, S. E., Echevarria, J., and Ros-Franch, S.: Southern Hemisphere Palaeobiogeography of Triassic-Jurassic Marine Bivalves, Springer Briefs Seaways and Landbridges: Southern Hemisphere Biogeographic Connections Through Time, Springer Science \& Business Media, Berlin, https://doi.org/10.1007/978-94-007-5098-2_1, 2013.

Danisch, J., Kabiri, L., Nutz, A., and Bodin, S.: Chemostratigraphy of Late Sinemurian-Early Pliensbachian shallow-to deepwater deposits of the Central High Atlas Basin: Paleoenvironmental implications, J. Afr. Earth Sci., 153, 239-249, https://doi.org/10.1016/j.jafrearsci.2019.03.003, 2019.

Davies, J. H. F. L., Marzoli, A., Bertrand, H., Youbi, N., Ernesto, M., and Schaltegger, U.: End-Triassic mass extinction started by intrusive CAMP activity, Nat. Commun., 8, 15596, https://doi.org/10.1038/ncomms15596, 2017.

Debrabant, P., Chamley, H., Deconinck, J. F., Récourt, P., and Trouiller, A.: Clay sedimentology, mineralogy and chemistry of Mesozoic sediments drilled in the northern Paris Basin, Sci. Dril., 3, 138-152, 1992.

Deconinck, J. F.: Identification de l'origine détritique ou diagénétique des assemblages argileux: le cas des alternances marne-calcaire du Crétacé inférieur subalpin, Bulletin de la Société Géologique de France, 3, 139-145, https://doi.org/10.2113/gssgfbull.III.1.139, 1987 (in French).

Deconinck, J. F. and Chamley, H.: Diversity of smectite origins in Late Cretaceous sediments: example of chalks from northern France, Clay Miner., 30, 365-379, https://doi.org/10.1180/claymin.1995.030.4.09, 1995.

Deconinck, J. F. and Debrabant, P.: Diagenèse des argiles dans le domaine subalpin: rôles respectifs de la lithologie, de l'enfouissement et de la surcharge tectonique, Revue de Géologie Dynamique et de Géographie Physique, 26, 321-330, 1985.

Deconinck, J. F., Hesselbo, S. P., and Pellenard, P.: Climatic and sea-level control of Jurassic (Pliensbachian) clay mineral sedimentation in the Cardigan Bay Basin, Llanbedr (Mochras Farm) borehole, Wales, Sedimentology, 66, 27692783, https://doi.org/10.1111/sed.12610, 2019.

Dellisanti, F., Pini, G. A., and Baudin, F.: Use of Tmax as a thermal maturity indicator in orogenic successions and comparison with clay mineral evolution, Clay Miner., 45, 115-130, https://doi.org/10.1180/claymin.2010.045.1.115, 2010.

Dera, G., Pucéat, E., Pellenard, P., Neige, P., Delsate, D., Joachimski, M. M., Reisberg, L., and Martinez, M.: Water mass exchange and variations in seawater temperature in the NW Tethys during the Early Jurassic: evidence from neodymium and oxygen isotopes of fish teeth and belemnites, Earth Planet. Sc. Lett., 286, 198-207, https://doi.org/10.1016/j.epsl.2009.06.027, 2009a.

Dera, G., Pellenard, P., Neige, P., Deconinck, J. F., Pucéat, E., and Dommergues, J. L.: Distribution of clay minerals in Early Jurassic Peritethyan seas: palaeoclimatic significance inferred from multiproxy comparisons, Palaeogeogr. Palaeocl., 271, 3951, https://doi.org/10.1016/j.palaeo.2008.09.010, 2009b.

Dera, G., Brigaud, B., Monna, F., Laffont, R., Pucéat, E., Deconinck, J. F., Pellenard, P., Joachimski, M. M., and Durlet, C.: Climatic ups and downs in a disturbed Jurassic world, Geology, 39, 215-218, https://doi.org/10.1130/G31579.1, 2011.

Dera, G., Prunier, J., Smith, P. L., Haggart, J. W., Popov, E., Guzhov, A., Rogov, M., Delsate, D., Thies, D., Cuny, G., Pucéat, E., Charbonnier, G., and Bayon, G.: Nd isotope constraints on ocean circulation, paleoclimate, and continental drainage during the Jurassic breakup of Pangea, Gondwana Res., 27, 1599-1615, https://doi.org/10.1016/j.gr.2014.02.006, 2015.

Disnar, J. R., Le Strat, P., Farjanel, G., and Fikri, A.: Sédimentation de la matière organique dans le nord-est du Bassin de Paris : conséquences sur le dépôt des argilites carbonées $\mathrm{du}$ Toarcien inférieur (Organic matter sedimentation in the northeast of the Paris Basin: consequences on the deposition of the lower Toarcian black shales), Chem. Geol., 131, 15-35, https://doi.org/10.1016/0009-2541(96)00021-6, 1996 (in French).

Dobson, M. R. and Whittington, R. J.: The geology of Cardigan Bay, P. Geologist. Assoc., 98, 331-353, https://doi.org/10.1016/S0016-7878(87)80074-3, 1987.

Duarte, L. V., Comas-Rengifo, M. J., Silva, R. L., Paredes, R., and Goy, A.: Carbon isotope stratigraphy and ammonite biochronostratigraphy across the Sinemurian-Pliensbachian boundary in the western Iberian margin, B. Geosci., 89, 719-736, https://doi.org/10.3140/bull.geosci.1476, 2014.

Fauconnier, D.: Jurassic palynology from a borehole in the Champagne area, France-correlation of the lower Callovian-middle Oxfordian using sequence stratigraphy, Rev. Palaeobot. Palyno., 87, 15-26, https://doi.org/10.1016/0034-6667(94)001427, 1995.

Franceschi, M., Corso, J. D., Cobianchi, M., Roghi, G., Penasa, L., Picotti, V., and Preto, N.: Tethyan carbonate platform transformations during the Early Jurassic (SinemurianPliensbachian, Southern Alps): Comparison with the Late Triassic Carnian Pluvial Episode, GSA Bulletin, 131, 1255-1275, https://doi.org/10.1130/B31765.1, 2019.

Gibbs, R. J.: Clay mineral segregation in the marine environment, J. Sediment. Petrol., 47, 237-243, https://doi.org/10.1306/ 212F713A-2B24-11D7-8648000102C1865D, 1977.

Godet, A., Bodin, S., Adatte, T., and Föllmi, K. B.: Platforminduced clay-mineral fractionation along a northern Tethyan basin-platform transect: implications for the interpretation of Early Cretaceous climate change (Late Hauterivian-Early Aptian), Cretaceous Res., 29, 830-847, https://doi.org/10.1016/j.cretres.2008.05.028, 2008.

Gómez, J. J., Comas-Rengifo, M. J., and Goy, A.: Palaeoclimatic oscillations in the Pliensbachian (Early Jurassic) of the Asturian Basin (Northern Spain), Clim. Past, 12, 1199-1214, https://doi.org/10.5194/cp-12-1199-2016, 2016.

Guillocheau, F., Robin, C., Allemand, P., Bourquin, S., Brault, N., Dromart, G., Friedenberg, R., Garcia, J. P., Gaulier, J. M., Gaumet, F., Grosdoy, B., Hanot, F., Le Strat, P., Mettraux, M., Nalpas, T., Prijac, C., Rigollet, C., Serrano, O., and Grandjean, G.: Meso-Cenozoic geodynamic evolution of the Paris Basin: 3D stratigraphic constraints, Geodin. Acta, 13, 189-245, https://doi.org/10.1080/09853111.2000.11105372, 2000. 
Hallam, A.: Evidence of sea-level fall in sequence stratigraphy: Examples from the Jurassic, Geology, 27, 343-346, https://doi.org/10.1130/00917613(1999)027<0343:EOSLFI>2.3.CO;2, 1999.

Hallam, A.: Evidence of sea-level fall in sequence stratigraphy: Examples from the Jurassic: Comment and Reply: REPLY, Geology, 28, 96, https://doi.org/10.1130/00917613(2000)28<96:EOSFIS>2.0.CO;2, 2000.

Han, G., Préat, A., Chamley, H., Deconinck, J. F., and Mansy, J. L.: Palaeozoic clay mineral sedimentation and diagenesis in the Dinant and Avesnes basins (Belgium, France): relationships with variscan tectonism, Sediment. Geol., 136, 217-238, https://doi.org/10.1016/S0037-0738(00)00103-2, 2000.

Haq, B. U.: Jurassic Sea level Variations: A Reappraisal, GSA today, 28, 4-10, https://doi.org/10.1130/GSATG359A.1, 2018.

Hardenbol, J., Thierry, J., Farley, M. B., Jacquin, T., de Graciansky, P. C., and Vail, P. R.: Mesozoic and Cenozoic sequence chronostratigraphic framework of European basins. Mesozoic and Cenozoic Sequence Stratigraphy of European Basins, SEPM Spec. P. No. 60, 3-13, 1998.

Hesselbo, S. P.: Sequence stratigraphy and inferred relative sealevel change from the onshore British Jurassic, P. Geologist. Assoc., 119, 19-34, https://doi.org/10.1016/S0016-7878(59)800699, 2008.

Hesselbo, S. P., Meister, C., and Gröcke, D. R.: A potential global stratotype for the Sinemurian-Pliensbachian boundary (lower Jurassic), Robin Hood's Bay, UK: ammonite faunas and isotope stratigraphy, Geol. Mag., 137, 601-607, 2000.

Hesselbo, S. P., Deconinck, J. F., Huggett, J. M., and MorgansBell, H. S.: Late Jurassic palaeoclimatic change from clay mineralogy and gamma-ray spectrometry of the Kimmeridge Clay, Dorset, UK, J. Geol. Soc., 166, 1123-1133, https://doi.org/10.1144/0016-76492009-070, 2009.

Hesselbo, S. P., Bjerrum, C. J., Hinnov, L. A., MacNiocaill, C., Miller, K. G., Riding, J. B., van de Schootbrugge, B., and the Mochras Revisited Science Team: Mochras borehole revisited: a new global standard for Early Jurassic earth history, Sci. Dril., 16, 81-91, https://doi.org/10.5194/sd-16-81-2013, 2013.

Hesselbo, S. P., Hudson, A. J. L., Huggett, J. M., Leng, M. J., Riding, J. B., and Ullmann, C. V.: Palynological, geochemical, and mineralogical characteristics of the Early Jurassic Liasidium Event in the Cleveland Basin, Yorkshire, UK, Newsl. Stratigr., 53, 191-211, https://doi.org/10.1127/nos/2019/0536, 2020.

Hillier, S., Wilson, M. J., and Merriman, R. J.: Clay mineralogy of the Old Red Sandstone and Devonian sedimentary rocks of Wales, Scotland and England, Clay Miner., 41, 433-471, https://doi.org/10.1180/0009855064110203, 2006.

Holford, S. P., Green, P. F., and Turner, J. P.: Palaeothermal and compaction studies in the Mochras borehole (NW Wales) reveal early Cretaceous and Neogene exhumation and argue against regional Palaeogene uplift in the southern Irish Sea, J. Geol. Soc., 162, 829-840, https://doi.org/10.1144/0016-764904-118, 2005.

Hudson, J. D.: Stable isotopes and limestone lithification, J. Geol. Soc., 133, 637-660, https://doi.org/10.1144/gsjgs.133.6.0637, 1977.

Hurst, A.: The implications of clay mineralogy to palaeoclimate and provenance during the Jurassic in NE Scotland, Scot. J. Geol., 21, 143-160, https://doi.org/10.1144/sjg21020143, 1985.
Jacquin, T., Dardeau, G., Durlet, C., de Graciansky, P.-C., and Hantzpergue, P.: The North-Sea cycle: an overview of 2ndorder transgressive/regressive facies cycles in western Europe, in: Mesozoic and Cenozoic Sequence Stratigraphy of European Basins, edited by: de Graciansky, P. C., Hardenbol, J., Jacquin, T., Vail, P. R., and Farley, M. B., SEPM Spec. P., 60, 445-466, 1998.

Jeans, C. V.: Clay mineralogy of the Jurassic strata of the British Isles, Clay Miner., 41, 187-307, https://doi.org/10.1180/0009855064110198, 2006.

Jeans, C. V., Mitchell, J. G., Fisher, M. J., Wray, D. S., and Hall, I. R.: Age, origin and climatic signal of English Mesozoic clays based on K/Ar signatures, Clay Miner., 36, 515-539, https://doi.org/10.1180/0009855013640006, 2001.

Jenkyns, H. C. and Weedon, G. P.: Chemostratigraphy $\left(\mathrm{CaCO}_{3}\right.$, TOC, $\delta^{13} \mathrm{C}_{\text {org }}$ ) of Sinemurian (Lower Jurassic) black shales from the Wessex Basin, Dorset and palaeoenvironmental implications, Newsl. Stratigr., 46, 1-21, https://doi.org/10.1127/00780421/2013/0029, 2013.

Jenkyns, H. C., Jones, C. E., Gröcke, D. R., Hesselbo, S. P., and Parkinson, D. N.: Chemostratigraphy of the Jurassic System: applications, limitations and implications for palaeoceanography, J. Geol. Soc., 159, 351-378, https://doi.org/10.1144/0016-764901130, 2002.

Jones, C. E., Jenkyns, H. C., and Hesselbo, S. P.: Strontium isotopes in Early Jurassic seawater, Geochim. Cosmochim. Ac., 58, 12851301, https://doi.org/10.1016/0016-7037(94)90382-4, 1994.

Kemp, S. J., Merriman, R. J., and Bouch, J. E.: Clay mineral reaction progress - the maturity and burial history of the Lias Group of England and Wales, Clay Miner., 40, 43-61, https://doi.org/10.1180/0009855054010154, 2005.

Korte, C. and Hesselbo, S. P.: Shallow-marine carbon- and oxygenisotope and elemental records indicate icehouse-greenhouse cycles during the Early Jurassic, Paleoceanography, 26, PA4219, https://doi.org/10.1029/2011PA002160, 2011.

Korte, C., Hesselbo, S. P., Ullmann, C. V., Dietl, G., Ruhl, M., Schweigert, G., and Thibault, N.: Jurassic climate mode governed by ocean gateway, Nat. Commun., 6, 1-7, https://doi.org/10.1038/ncomms10015, 2015.

Korte, C., Ruhl, M., Pálfy, J., Ullmann, C. V., and Hesselbo, S. P.: Chemostratigraphy across the Triassic-Jurassic boundary, in: Chemostratigraphy Across Major Chronological Boundaries, edited by: Sial, A. N., Gaucher, C., Ramkumar, M., and Ferreira, V. P., The American Geophysical Union, Geophysical Monograph 240, 183-210, 2019.

Lang, W. D.: The Coinstone of the Charmouth Lias, Proceedings of the Dorset Natural History and Archaeological Society, 67, 145149, 1945.

Lanson, B., Sakharov, B. A., Claret, F., and Drits, V. A.: Diagenetic smectite-to-illite transition in clay-rich sediments: A reappraisal of X-ray diffraction results using the multi-specimen method, Am. J. Sci., 309, 476-516, https://doi.org/10.2475/06.2009.03, 2009.

Lefrançois, A., Deconinck, J. F., Mansy, J. L., and Proust, J. N.: Structure, sédimentologie et minéralogie des argiles des formations de Beaulieu et d'Hydrequent (Dévonien supérieur du BasBoulonnais), Annales de la Société géologique du Nord, 2, 123134, 1993 (in French). 
Lehmann, M. F., Bernasconi, S. M., Barbieri, A., and McKenzie, J. A.: Preservation of organic matter and alteration of its carbon and nitrogen isotope composition during simulated and in situ early sedimentary diagenesis, Geochim. Cosmochim. Ac., 66, 35733584, https://doi.org/10.1016/S0016-7037(02)00968-7, 2002.

Levert, J. and Ferry, S.: Diagenèse argileuse complexe dans le mésozoïque subalpin révélée par cartographie des proportions relatives d'argiles selon des niveaux isochrones, Bulletin de la Société Géologique de France, 4, 1029-1038, https://doi.org/10.2113/gssgfbull.IV.6.1029, 1988 (in French).

Marshall, J. D.: Climatic and oceanographic isotopic signals from the carbonate rock record and their preservation, Geol. Mag., 129, 143-160, https://doi.org/10.1017/S0016756800008244, 1992.

Marzoli, A., Renne, P. R., Piccirillo, E. M., Ernesto, M., Bellieni, G., and De Min, A.: Extensive 200-million-year-old continental flood basalts of the Central Atlantic Magmatic Province, Science, 284, 616-618, https://doi.org/10.1126/science.284.5414.616, 1999.

Masetti, D., Figus, B., Jenkyns, H. C., Barattolo, F., Mattioli, E., and Posenato, R.: Carbon-isotope anomalies and demise of carbonate platforms in the Sinemurian (Early Jurassic) of the Tethyan region: evidence from the Southern Alps (Northern Italy), Geol. Mag., 154, 625-650, https://doi.org/10.1017/S0016756816000273, 2017.

McHone, J. G.: Non-plume magmatism and rifting during the opening of the central Atlantic Ocean, Tectonophysics, 316, 287-296, https://doi.org/10.1016/S0040-1951(99)00260-7, 2000.

Mercuzot, M., Pellenard, P., Durlet, C., Bougeault, C., Meister, C., Dommergues, J. L., Thibault, N., Baudin, F., Mathieu, O., Bruneau, L., Huret, E., and El Hmidi, K.: Carbon-isotope events during the Pliensbachian (Lower Jurassic) on the African and European margins of the NW Tethyan Realm, Newsl. Stratigr., 53, 41-69, https://doi.org/10.1127/nos/2019/0502, 2020.

Merriman, R. J.: Clay mineral assemblages in British Lower Palaeozoic mudrocks, Clay Miner., 41, 473-512, https://doi.org/10.1180/0009855064110204, 2006.

Meyers, P. A.: Preservation of elemental and isotopic source identification of sedimentary organic matter, Chem. Geol., 114, 289302, https://doi.org/10.1016/0009-2541(94)90059-0, 1994.

Moore, D. M. and Reynolds, R. C.: X-Ray Diffraction and the Identification and Analysis of Clay Minerals, Oxford University Press, New York, 378 pp., ISBN 019508713 5, 1997.

Moreau, M. G., Bucher, H., Bodergat, A. M., and Guex, J.: Pliensbachian magnetostratigraphy: new data from Paris Basin (France), Earth Planet. Sc. Lett., 203, 755-767, https://doi.org/10.1016/S0012-821X(02)00898-1, 2002.

Müller, A., Parting, H., and Thorez, J.: Caractères sédimentologiques et minéralogiques des couches de passage du Trias au Lias sur la bordure nord-est du Bassin de Paris, Annales de la Société géologique de Belgique, 96, 671-707, 1973 (in French).

Osete, M. L., Gómez, J. J., Pavón-Carrasco, F. J., Villalaín, J. J., Palencia-Ortas, A., Ruiz-Martínez, V. C., and Heller, F.: The evolution of Iberia during the Jurassic from palaeomagnetic data, Tectonophysics, 502, 105-120, https://doi.org/10.1016/j.tecto.2010.05.025, 2011.

Page, K. N.: The Lower Jurassic of Europe: its subdivision and correlation, Geol. Surv. Den. Greenl., 1, 23-59, https://doi.org/10.34194/geusb.v1.4646, 2003.
Pellenard, P. and Deconinck, J. F.: Mineralogical variability of Callovo-Oxfordian clays from the Paris Basin and the Subalpine Basin, C. R. Geosci., 338, 854-866, https://doi.org/10.1016/j.crte.2006.05.008, 2006.

Peti, L., Thibault, N., Clémence, M. E., Korte, C., Dommergues, J. L., Bougeault, C., Pellenard, P., Jelby, M. E., and Ullmann, C. V.: Sinemurian-Pliensbachian calcareous nannofossil biostratigraphy and organic carbon isotope stratigraphy in the Paris Basin: calibration to the ammonite biozonation of NW Europe, Palaeogeogr. Palaeocl., 468, 142-161, https://doi.org/10.1016/j.palaeo.2016.12.004, 2017.

Petschick, R.: MacDiff 4.2.2, available at: http://servermac. geologie.uni-frankfurt.de/Staff/Homepages/Petschick/ classicsoftware.html (last access: 20 June 2021), 2000.

Plancq, J., Mattioli, E., Pittet, B., Baudin, F., Duarte, L. V., Boussaha, M., and Grossi, V.: A calcareous nannofossil and organic geochemical study of marine palaeoenvironmental changes across the Sinemurian/Pliensbachian (early Jurassic, $\sim 191 \mathrm{Ma})$ in Portugal, Palaeogeogr. Palaeocl., 449, 1-12, https://doi.org/10.1016/j.palaeo.2016.02.009, 2016.

Poças Ribeiro, N., Mendonça Filho, J. G., Duarte, L. V., Silva, R. L., Mendonça, J. O., and Silva, T. F.: Palynofacies and organic geochemistry of the Sinemurian carbonate deposits in the western Lusitanian Basin (Portugal): Coimbra and Água de Madeiros formations, Int. J. Coal Geol., 111, 37-52, https://doi.org/10.1016/j.coal.2012.12.006, 2013.

Porter, S. J., Selby, D., Suzuki, H., and Gröcke, D.: Opening of a trans Pangaean marine corridor during the Early Jurassic: insights from osmium isotopes across the Sinemurian-Pliensbachian GSSP, Robin Hood's Bay, UK, Palaeogeogr. Palaeocl., 375, 50-58, https://doi.org/10.1016/j.palaeo.2013.02.012, 2013.

Price, G. D., Baker, S. J., van de Velde, J., and Clémence, M. E.: High-resolution carbon cycle and seawater temperature evolution during the Early Jurassic (Sinemurian-Early Pliensbachian), Geochem. Geophy. Geosy., 17, 3917-3928, https://doi.org/10.1002/2016GC006541, 2016.

Riding, J. B., Leng, M. J., Kender, S., Hesselbo, S. P., and Feist-Burkhardt, S.: Isotopic and palynological evidence for a new early Jurassic environmental perturbation, Palaeogeogr. Palaeocl., 374, 16-27, https://doi.org/10.1016/j.palaeo.2012.10.019, 2013.

Raucsik, B. and Varga, A.: Climato-environmental controls on clay mineralogy of the Hettangian-Bajocian successions of the Mecsek Mountains, Hungary: an evidence for extreme continental weathering during the early Toarcian oceanic anoxic event, Palaeogeogr. Palaeocl., 265, 1-13, https://doi.org/10.1016/j.palaeo.2008.02.004, 2008.

Robaszynski, F., Pomerol, B., Masure, E., Bellier, J. P., and Deconinck, J. F.: Stratigraphy and stage boundaries in a type-section of the Late Cretaceous chalk from the East Paris basin: The "Craie 700" Provins boreholes, Cretaceous Res., 26, 157-169, https://doi.org/10.1016/j.cretres.2004.10.003, 2005.

Ruffell, A., McKinley, J. M., and Worden, R. H.: Comparison of clay mineral stratigraphy to other proxy palaeoclimate indicators in the Mesozoic of NW Europe, Philos. T. Roy. Soc. A, 360, 675-693, https://doi.org/10.1098/rsta.2001.0961, 2002.

Ruhl, M., Hesselbo, S. P., Hinnov, L., Jenkyns, H. C., Xu, W., Riding J. B., Storm M., Minisini D., Ullmann C. V., 
and Leng, M. J.: Astronomical constraints on the duration of the Early Jurassic Pliensbachian Stage and global climatic fluctuations, Earth Planet. Sc. Lett., 455, 149-165, https://doi.org/10.1016/j.epsl.2016.08.038, 2016.

Schöllhorn, I., Adatte, T., Van de Schootbrugge, B., Houben, A., Charbonnier, G., Janssen, N., and Föllmi, K. G.: Climate and environmental response to the break-up of Pangea during the Early Jurassic (Hettangian-Pliensbachian); the Dorset coast (UK) revisited, Global Planet. Change, 185, 103096, https://doi.org/10.1016/j.gloplacha.2019.103096, 2020a.

Schöllhorn, I., Adatte, T., Charbonnier, G., Mattioli, E., Spangenberg, J. E., and Föllmi, K. G.: Pliensbachian environmental perturbations and their potential link with volcanic activity: Swiss and British geochemical records, Sediment. Geol., 406, 105665, https://doi.org/10.1016/j.sedgeo.2020.105665, 2020b.

Shaw, H. F.: Clay mineralogy of Carboniferous sandstone reservoirs, onshore and offshore UK, Clay Miner., 41, 417-432, https://doi.org/10.1180/0009855064110202, 2006.

Spears, D. A.: Clay mineralogy of onshore UK Carboniferous mudrocks, Clay Miner., 41, 395-416, https://doi.org/10.1180/0009855064110201, 2006.

Stoll, H. M. and Schrag, D. P.: High-resolution stable isotope records from the Upper Cretaceous rocks of Italy and Spain: Glacial episodes in a greenhouse planet?, Geol. Soc. Am. Bull., 112, 308-319, https://doi.org/10.1130/00167606(2000)112<308:HSIRFT>2.0.CO;2, 2000.

Storm, M. S., Hesselbo, S. P., Jenkyns, H. C., Ruhl, M., Ullmann, C. V., Xu, W., Leng, M. J., Riding, J. B., and Gorbanenko, O.: Orbital pacing and secular evolution of the Early Jurassic carbon cycle, P. Natl. Acad. Sci. USA, 117, 3974-3982, https://doi.org/10.1073/pnas.1912094117, 2020.

Suan, G., van de Schootbrugge, B., Adatte, T., Fiebig, J., and Oschmann, W.: Calibrating the magnitude of the Toarcian carbon cycle perturbation, Paleoceanography, 30, 495-509, https://doi.org/10.1002/2014PA002758, 2015.

Šucha, V., Kraust, I., Gerthofferova, H., Peteš, J., and Serekova, M.: Smectite to illite conversion in bentonites and shales of the East Slovak Basin, Clay Miner., 28, 243-253, https://doi.org/10.1180/claymin.1993.028.2.06, 1993.

Tappin, D. R., Chadwick, R. A., Jackson, A. A., Wingfield, R. T. R., and Smith, N. J. P.: Geology of Cardigan Bay and the Bristol Channel, United Kingdom offshore regional report, British Geological Survey, HMSO, 107 pp, ISBN 011 884506 3, 1994.

Thierry, J., Barrier, E., Abbate, E., et al.: Middle Toarcian, in: Atlas Peri-Tethys Paleogeographical Maps, edited by: Dercourt, J., Gaetani, M., Vrielynck, B., Barrier, E., Biju-Duval, B., Brunet, M.-F., Cadet, J. P., Crasquin, S., and Sandulescu, M., CGMW, Paris, vol. IXX.CCGM/CGMW, map 8, 2000.
Tucker, R. M. and Arter, G.: The tectonic evolution of the North Celtic Sea and Cardigan Bay basins with special reference to basin inversion, Tectonophysics, 137, 291-307, https://doi.org/10.1016/0040-1951(87)90324-6, 1987.

Ullmann, C. V., Boyle, R., Duarte, L. V., Hesselbo, S. P., Kasemann, S. A., Klein, T., Lenton, T. M., Piazza, V., and Aberhan, M.: Warm afterglow from the Toarcian Oceanic Anoxic Event drives the success of deep-adapted brachiopods, Sci. Rep., 10, 6549, https://doi.org/10.1038/s41598-020-63487-6, 2020.

Ullmann, C. V., Szúcs, D., Jiang, M., Hudson, A. J., and Hesselbo, S. P.: Geochemistry of macrofossil, bulk rock, and secondary calcite in the Early Jurassic strata of the Llanbedr (Mochras Farm) drill core, Cardigan Bay Basin, Wales, UK, Journal of the Geological Society, accepted, 2021.

van de Schootbrugge, B., Bailey, T. R., Rosenthal, Y., Katz, M. E., Wright, J. D., Miller, K. G., Feist-Burkhardt, S., and Falkowski, P. G.: Early Jurassic climate change and the radiation of organicwalled phytoplankton in the Tethys Ocean, Paleobiology, 31, 7397, https://doi.org/10.1666/0094-8373(2005)0312.0.CO;2, 2005. van de Schootbrugge, B., Richoz, S., Pross, J., Luppold, F. W., Hunze, S., Wonik, T., Blau, J., Meister, C., Van der Weijst, C. M. H., Suan, G., Fraguas, A., Fiebig, J., Herrle, J. O., Guex, J., Little, C. T. S., Wignall, P. B., Püttmann, W., and Oschmann, W.: The Schandelah Scientific Drilling Project: A 25-million-year record of Early Jurassic palaeo-environmental change from northern Germany, Newsl. Stratigr., 52, 249-296, https://doi.org/10.1127/nos/2018/0259, 2019.

Wall, D.: Microplankton, pollen, and spores from the Lower Jurassic in Britain, Micropaleontology, 11, 151-190, 1965.

Wood, A. and Woodland, A. W.: Borehole at Mochras, west of Llanbedr, Merionethshire, Nature, 219, 1352, https://doi.org/10.1038/2191352a0, 1968.

Woodland, A. W. (Ed.): The Llanbedr (Mochras Farm) Borehole, Institute of Geological Sciences, London, Report No. 71/18, 115 pp., 1971.

Xu, W., Ruhl, M., Jenkyns, H. C., Leng, M. J., Huggett, J. M., Minisini, J. M., Ullmann, C. V., Riding, J. B., Weijers, J. W. H., Storm, M. S., and Hesselbo, S. P.: Evolution of the Toarcian (Early Jurassic) carbon-cycle and global climatic controls on local sedimentary processes (Cardigan Bay Basin, UK) Earth Planet. Sc. Lett., 484, 396-411, https://doi.org/10.1016/j.epsl.2017.12.037, 2018.

Yang, Z., Moreau, M. G., Bucher, H., Dommergues, J. L., and Trouiller, A.: Hettangian and Sinemurian magnetostratigraphy from Paris Basin, J. Geophys. Res., 101, 8025-8042, https://doi.org/10.1029/95JB03717, 1996. 